\title{
Oraların Nesi Meşhur: Şehir Pazarlamasında Coğrafi İşaret Tescilli Ürünler
}

\author{
DOI: 10.26466/opus.772918
}

\author{
* \\ Semih Sarripek* - Samet Cevik ** \\ * Öğr. Gör., Bandırma Onyedi Eylül Üniversitesi, Erdek Meslek Yüksekokulu, Balıkesir \\ E-Posta: ssariipek@bandirma.edu.tr \\ ORCID: 0000-0002-6585-626X \\ ** Dr. Öğr. Üyesi, Bandırma Onyedi Eylül Üniversitesi, Erdek Meslek Yüksekokulu, Balıkesir \\ E-Posta: scevik@bandirma.edu.tr \\ ORCID: $\quad$ 0000-0003-0859-6673
}

\section{Öz}

Şehirlerin kimliğinin bir parçasını oluşturan coğrafi işaret tescilli ürünler, hem ürünü tanıtarak orijinal haliyle gelecek kuşaklara aktarılmasını ve kültürel mirasın sürdürülebilirliğini sağlamakta hem de üretildiği yörenin tanıtım ve turizm çalışmalarına katkı vererek pazarlama ve markalama anlamında önemli bir rol oynamaktadır. Bu bağlamda şehir yönetiminde söz sahibi olan kurumlarm bu ürünlere gereken önemi vererek şehir pazarlaması çalışmalarında web sayfaları aracılığıyla bu ürünlerden azami düzeyde yararlanmaları gerekmektedir. Bu doğrultuda bu araştırmada şehir pazarlamasında coğrafi işaret tescilli ürünlerin kullanımını değerlendirmek amaçlanmıştır. Bu amaçla nitel araştırma yöntemlerinden içerik analizi tekniğiyle 81 ilin belediye, valilik ile il, kültür ve turizm müdürlü̆̈̈̈ web siteleri incelenmiş ve web sitelerinde tescile dair bilgiler, görsel öğeler, ürünün tarihi, toplumsal değeri ve turistik önemine dair bilgilerin olup olmadığı araştırılmıştır. Çalışmanın bulguları, coğrafi işaret tescilli ürünlerin günümüzde değerinin tam olarak anlaşılmadığın ya da kurumlar tarafından bu ürünlere verilen önemin yeterli olmadı̆̆ını ortaya koyarken bu konuda çalışmalar yapan kurumların da bulunduğunu fakat genele oranla sayılarının yok denilebilecek kadar az olduğunu göstermektedir.

Anahtar Kelimeler: Şehir Pazarlaması, Coğrafi İşaretleme Sistemi, Coğrafi İşaret Tescilli Ürünler 


\title{
What is Famous There: Geographical Indication Registered Products in City Marketing
}

\begin{abstract}
Geographical indication registered products which form a part of the identity of the cities both ensure that the product is transferred to future generations in its original form by promoting the product and thus the sustainability of the cultural heritage and also play an important role in marketing and branding by contributing to the promotion and tourism activities of the region where they are produced. In this context, institutions that have a voice in city management should benefit at the maximum level from these products in city marketing activities by giving sufficient importance to these products. The aim of the study is to evaluate the use of geographical indication registered products in city marketing. For this purpose, through content analysis technique, among the qualitative research methods, web sites of municipality, governorship and provincial directorate of culture and tourism of 81 provinces were examined and it was investigated whether there is information regarding registration information, visual items, the history, social value and touristic importance of the product. While the findings of the study reveal that the value of the geographical indication registered products is not fully understood or the importance given to these products by the institutions is not sufficient, they also indicate that there are institutions work on this subject but their number is very low compared to the general.
\end{abstract}

Keywords: City Marketing, Geographical Indication System, Geographical Indication Registered Products 


\section{Giriş}

Şehirler, çeşitli ekonomik, siyasi ya da sosyo-psikolojik hedeflerin takibinde bireyselliklerini korumak amaçlı birbirlerinden farklılaşmaya ihtiyaç duymaktadırlar. Bu doğrultuda şehir yönetimleri, tasarlanmış bir kimliği şekillendirme ve ister dış ister iç olsun bu kimliği tanımlanmış pazarlara teşvik etmeye çalışmaktadırlar (Kavaratzis ve Ashworth, 2006). Her şehir sahip olduğu bu özgün kimliği aracılığıyla diğer şehirlerden ayrılmaktadır. Ancak bu kimlik yeterince tanıtılmadığında kimliği oluşturan unsurlar yeterince bilinmeyecek ve kimlik, şehrin imajina yansıyamayacaktır. Dolayısıyla etkin bir şehir pazarlaması ile bu kimliğin ön plana çıarılıp tanıtılması ve geniş kitlelerce bilinir hale getirilmesi önem arz etmektedir (Polat, 2007, s.236). Şehir pazarlamasi; belirlenen hedefler doğrultusunda ilgili alanın etkin sosyal ve ekonomik işlevini en üst düzeye çıkarmak için kentsel faaliyetlerin hedef pazarın talepleriyle mümkün olduğunca yakından ilişkili olduğu bir süreç olarak tanımlanmıştır (Ashworth ve Voogd, 1988, s.68). Şehir pazarlamasının temel amacı, bir şehri içindeki değerler ile birlikte pazarlayarak yeni bir değer artı̧ı gerçekleştirmek veya bir ülkenin başka şehirlerinde mevcut olan üretim, yatırım ve tüketim potansiyeli veya eğitim talebi gibi değerleri ilgili şehre transfer edilmesini sağlayarak bir değer artışı gerçekleştirmektir (Polat, 2007, s.234).

Şehir pazarlanmasında şehirdeki tüm paydaşların rolü olmakla birlikte yerel yönetimlere önemli görevler düşmektedir. Yerel yönetimler, turizm gelişimini teşvik etme ve bu gelişimi şekillendirmede önemli bir rol oynamaktadır. Yerel yönetimler, stratejik planlama, politika oluşturma ve uygulama (ekonomik kalkınma, fiziksel gelişme, pazarlama ve tutundurma); ziyaretçi bilgilendirme hizmetlerinin sağlanması; çekiciliklerin ve etkinliklerin yönetimi; destinasyon tabanlı kamu/özel ortaklıkların koordinasyonu; araştırma; ziyaretçi hizmetleri; kamu arazi yönetimi gibi turizmle ilgili bir dizi faaliyeti yürütmektedir (Can vd., 2014, s.192). Rainisto (2003, s.16), bir şehir için ilave değerlerin yaratılması sürecinin dört adımdan oluştuğunu belirtmiştir. Buna göre ilk olarak bir şehir vatandaşların, işletmelerin ve ziyaretçilerin memnuniyeti için temel hizmetler ve gerekli altyapıyı sağlamalıdır. İkinci adım olarak bir şehir, mevcut iş ve kamu desteğini sürdürmek ve yeni yatırımlar, işletmeler ya da insanlar getirmek için yeni çekicilik merkezlerine ihtiyaç duyabilir. Üçüncü olarak bir şehir, güçlü bir imaj ve iletişim programı ile şehrin 
faydalarını ve ayırt edici özelliklerini iletebilmelidir. Son adım olarak ise bir şehir yeni şirketler, yatırımlar ve ziyaretçiler çekmek için vatandaşlar, liderler ve kurumlardan destek sağlamalıdır. Buradaki üçüncü adım olarak belirtilen, şehirlerin kimliklerini oluşturan ve diğer şehirlerden ayrılmasını sağlayan özgün kimliklerini oluşturan unsurları etkin bir biçimde pazarlayabilmelerini ifade etmektedir.

Günümüzde turizm bölgelerinin pazarlanmasında olduğu gibi şehirlerin kimliklerini oluşturan unsurlarını pazarlamasında da etkin bir araç olarak internetin rolü büyüktür. Yerel yönetimlerin web sitelerinin şehir pazarlamasinda etkinliğini belirleyen çalışmalardan birinde Güçer vd. (2013), büyükşehir belediyelerinin web sitelerini incelemişler ve önemli bulgular elde etmişlerdir. Büyükşehir belediyeleri web sitelerinde çeşitli alanlarda ilgili başlıklar olmasına rağmen bu başlıklar altındaki unsurların sadece bilgi amaçlı yer aldığı, çekicilik özelliklerinin ön plana çıkarılması doğrultusunda faaliyetlerin eksik kaldığı görülmüştür. Turizmde önemli bir konumda bulunan şehirlerin belediye yönetimlerinin, web sitelerini bu amaçla daha etkin kullandıkları; turizmden fazla pay almayan şehirlerde ise bu konunun daha zayıf kaldığı ortaya çıkmıştır. Bir diğer önemli bulgu da web sitesi aracılığıyla yapılan şehir pazarlaması çalışmalarında belediyelerin web sitelerini kendilerini yerel halka tanıtacak şekilde tasarlamalarıdır. Sayfaların yabancı dildeki versiyonlarının da bu doğrultuda hazırlandığı dikkat çekici bir sonuçtur. Bir diğer çalışmada Ertaş vd. (2020), Türkiye'deki büyükşehir belediye web sitelerini şehir turizmi bağlamında analiz etmişlerdir. Çalışma sonucunda turizmle ilgili bilgilerin tamamına yer veren bir şehir olmadığına ulaşılmıştır. Özellikle yabancı turistlerin tatil seçimi sürecinde gereksinim duydukları bilgiler web sitelerinde bulunmamaktadır. Güçer vd.'nin çalışma sonucuna benzer olarak, Türkiye'deki büyükşehirlerin web sitelerini o kentte yaşayan yerel halka yönelik hazırladıkları, turistler için gerekli olan bilgilere yeterince önem vermedikleri, turizmin arka planda bırakıldığı ve web sitelerinin şehir turizmi açısından bir pazarlama aracı olarak kullanılamadığı sonucuna ulaşılmıştır. Ünal ve Çelen (2020) Akdeniz Bölgesi destinasyonlarının bir pazarlama aracı olarak web sitelerini analiz ettikleri çalışmalarında Akdeniz Bölgesi destinasyonlarının \%91'inin kendilerine ait bir web sitelerinin olmadığ 1 ve bağlı bulundukları valilik, belediye ve il kültür turizm müdürlüklerinde de detaylı bilgilerin bulunmadığ belirlenmiştir. Web sitesi olan destinasyonların ise 
destinasyon pazarlaması bağlamında yeterli olmadıkları sonucuna ulaşılmıştır. Gümüş (2018) ise 81 ilin valiliğinin pazarlama aracı olarak sosyal medya kullanımını analiz etmiştir. Valiliklerin resmi sosyal medya sayfalarında paylaştıkları içeriklerin incelendiği çalışmada valiliklerin gerek halkla ilişkiler gerekse kamusal pazarlama çalışmaları bağlamında sosyal medya mecralarından yeterince yararlanamadıkları sonucuna ulaşılmıştır.

$\mathrm{Bu}$ çalışmada ise şehir pazarlamasında önemli aktörlerden olan belediye, valilik ve il kültür ve turizm müdürlügü web siteleri incelenmiştir. 81 ilin dâhil ediği çalışmada, şehirlerin kimliklerinin önemli bir parçasını oluşturan ve diğer şehirlerden farklılaşmasını ifade eden coğrafi işaret tescilli ürünlerine odaklanılmıştır. 81 ilin belediye, valilik ve il kültür ve turizm müdürlüklerinin web siteleri aracılığıyla şehir pazarlamasında coğrafi işaret tescilli ürünlerden ne ölçüde yararlandıkları belirlenen kriterlere göre analiz edilmiştir.

\section{Coğrafi İşaretleme}

Coğrafi işaretli ürünlerin tescilinden sorumlu olan Türk Patent ve Marka Kurumu Haziran 2020'de güncellediği “Coğrafi Isşaretler ve Geleneksel Ürün Adları" isimli kılavuzda coğrafi işareti, "temel olarak benzerlerinden farklılaşmış ve bu farkı kaynaklandığı yöreye borçlu olan bir yöresel ürün adı" şeklinde ifade etmiştir. Bu anlamda coğrafi işaret, belirgin bir niteliği, ünü veya diğer özellikleri bakımından kökenin bulunduğu yöre, alan, bölge veya ülke ile özdeşleşmiş bir ürünü gösteren işarettir. Coğrafi işaretler menşe adı ve mahreç işareti olmak üzere ikiye ayrılmakta ve bunların dışında menşe adı ve mahreç işareti kapsamına girmeyen geleneksel ürün adı isimli bir sinıflandırma bulunmaktadır. (Türk Patent ve Marka Kurumu, 2020a):

* Menşe ad1; "coğrafi sinırlar belirlenmiş bir yöre, bir bölge veya istisnai durumlarda ülkeden kaynaklanan, tüm veya esas özelliklerini bu coğrafi alana özgü do$\breve{g}$ al ve beşeri unsurlardan alan, üretimi, işlenmesi ve diğer işlemlerin tümü bu coğrafi alanın stnırlar içinde gerçekleşen ürünleri tanmmlayan adlan" ifade eder. Menşe adları sadece ait oldukları coğrafi bölgede üretilirler.

* Mahreç işareti ise "coğrafi sınırları belirlenmiş bir yöre, bölge veya ülkeden kaynaklanan, belirgin bir niteliği, ünü veya diğer özellikleri bakımından bu coğrafi alan ile özdeşleşen, üretimi, işlenmesi ve diğer işlemlerinden en az biribelirlenmiş coğrafi alanın sinırlar içinde yapılan ürünleri tanımlayan adlar" ş̧eklinde tanimlanmaktadır. 
* Geleneksel ürün adı, ilgili piyasada bir ürünü tarif etmek için geleneksel olarak en az 30 yıl süreyle kullanıldığı kanıtlanan adları temsil etmektedir. "Geleneksel üretim veya işleme yöntemi yahut geleneksel bileşimden kaynaklanması" ve "geleneksel hammadde veya malzemeden üretilmiş olması" şartlarından birini sağlayan ürünler geleneksel ürün adı olarak tanımlanır.
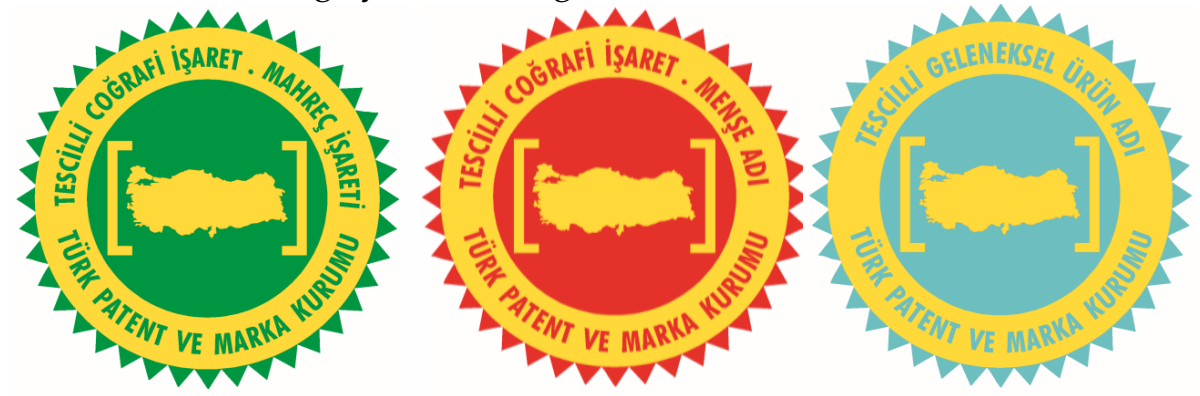

Şekil 1. Coğrafi İşaret Logoları (Kaynak: Türk Patent ve Marka Kurumu, 2019)

Bir ürünün coğrafi işaret olarak nitelenmesi için bazı unsurları taşıması gerekmektedir. Bu unsurlar şu şekilde sıralanabilir (Kan ve Gülçubuk, 2008, s.59):

* Ürün: Coğrafi işaretin bir ürünü belirtmesi gerekir. Coğrafi işaret bir ürünün kökenini belirtir ve diğer ürünlerden ayırt edilmesini sağlar.

* Belirli bir coğrafya: Coğrafi işaretler sınırları belirlenmiş bir coğrafyadan kaynaklanan ürünleri ifade eder.

* İşaret: Coğrafi işaretler, ürünleri ayırt etmeye ve kullanıldıkları ürünleri farklılaştırmaya yarayan işaretlerdir. Bu ürünlerin üzerinde yer alan ad, işaret ve ifadeler işaret unsuru olarak karşımıza çıkmaktadır.

* Ürünün belli bir karakteristik taşıması: Coğrafi işaretli ürünler yetiştirildiği alandan dolayı bir özellik kazanmış, benzerlerine göre farklılaştırılmış ürünlerdir.

* Ürünün karakteristik özelliği ile coğrafi kökeni arasında ilişki olması: Bu özellik hem kültürel mirasın korunması hem de tüketicinin karar alma sürecini etkileyen ve ürünün bazı özellikleri hakkında tüketiciye bilgi veren bir unsurdur.

Coğrafi işaretlere yönelik ilk yasal düzenleme AB ölçeğinde 1992 yılında uygulanmaya başlamıştır. Yapılan düzenlemeler çerçevesinde birçok ürün 
tescillenerek koruma altına alınmıştır. Koruma altına alınan ürünler gıda piyasalarının en çok talep edilen ürünleri olup Avrupa Gıda Sisteminde ortaya çıkan gida krizlerinde talepleri daha fazla artan ürünler arasında yer almaktadır (Orhan, 2010). Türkiye'de ilk olarak 1995 yılında yürürlüğe giren 555 sayılı Coğrafi İşaretlerin Korunması Hakkında Kanun Hükmünde Kararname ve 555 sayılı Coğrafi İşaretlerin Korunması Hakkında Kanun Hükmünde Kararnamenin Uygulama Şeklini Gösterir Yönetmelik kapsamında ürünler coğrafi işaret adı altında koruma altına alınmaya başlamıştır (Kan ve Gülçubuk, 2008, s.63). 555 sayılı KHK 22.12.2016 tarihli ve 6769 sayılı Kanunun 191. Maddesiyle yürürlükten kaldırılmıştır. Ancak 6769 sayılı Kanunun geçici maddeleri gereğince mülga KHK'nin bazı hükümlerin uygulanmasına devam edileceğinden uygulayıcıya kolaylık sağlaması amacıyla 555 sayılı KHK sistemde korunmuştur (Mevzuat Bilgi Sistemi, 2018). Türkiye'de uygulanan coğrafi işaret sisteminin $\mathrm{AB}$ ülkelerinden farklı olan bazı özellikleri bulunmaktadır. $\mathrm{AB}$ içerisinde tarımsal olmayan ürünler coğrafi işaret sistemi içerisinde bulunmazken Türkiye'de gida ve tarım kapsamında yer almayan ürünler de coğrafi işaret olarak tescillenebilmektedir. Bu durum, Türkiye'de coğrafi işaretlerin sadece gastronomi turizmine değil aynı zamanda kültür turizmi, kültürel miras turizmi, ekoturizm gibi turizm türlerine de hizmet ettiğini göstermektedir (Kan vd., 2012).

T.C. Kültür ve Turizm Bakanlığı tarafından yayınlanan Tanıtma Bülteni'nde (2018) coğrafi işaret tescilli ürünler; yerel çekicilikleri bünyesinde barındıran, kültürel miras olarak değerlendirilebilen, geleneksel değerleri ilgi odağ 1 haline getirebilen ve yöresel ürünleri turistik bir değere dönüştürme potansiyeli olan ürünler olarak tanımlanmıştır. Coğrafi işaret tescilli ürünler; sürdürülebilir gastronomi turizminin motivasyon faktörü olan geleneksel üretimi, geleneksel yaşam kültürünü, yöresel lezzetleri koruyup tanitarak ve bölgenin turizm potansiyelini destekleyerek turist çekmede etkili olmaktadır (Durlu Özkaya vd., 2013).

Literatürde coğrafi işaretli ürünlerin turizmdeki rolüne odaklanan birçok çalışmaya rastlanmıştır. Orhan (2010) Kocaeli'nin coğrafi işaretli ürünü olan pişmaniyenin kültürel, ekonomik, turistik ve sosyal bağlamda kente olan katkılarını ele aldığı çalışmasında pişmaniyenin üretim sorunlarını tespit etmiş ve birtakım önerilerde bulunmuştur. Bir başka çalışmada Şahin (2013), Kırklareli ilinin Vize ilçesinin potansiyel coğrafi işaretli ürünlerini inceleyerek bu 
ürünlerin tescillenmesi durumunda bölgeye sağlayabileceği faydaları değerlendirmiştir. Mercan ve Üzülmez (2014) çalışmalarında Çanakkale ilinin tescil almış olan coğrafi işaretli ürünlerinin bölgesel turizm gelişimindeki önemini araştırmışlardır. Çalışmadan çıkan en önemli sonuçlardan biri, ürünlerin tanıtım faaliyetlerinin yeteri kadar yapılmadığıdır. Yenipınar vd. (2014) de coğrafi işaretlemenin bölge turizmini geliştirmek için bir araç olarak kullanıldığına değinerek Van otlu peynirine yönelik bir araştırma gerçekleştirmişlerdir. Araştırma sonucunda Van otlu peyniri coğrafi tescilinin marka bir ürün yaratarak ilin turizm gelişimine, tanıtımına ve ekonomisine fayda sağlayacak güçlü bir araç konumunda olduğu sonucuna ulaşılmıştır. Yanar ve Özkan Tağı (2014), çalışmalarında Burdur iline ait coğrafi işaretli ürünleri belirleyerek turistik hediyelik eşya tasarımına yönelik özgün ürün önerileri geliştirmişlerdir. Vatansever Deviren ve Yıldız (2017), Muğla örnekleminde coğrafi işaretlerin bölgesel turizmdeki rolünü değerlendirmişlerdir. Yazarlar Muğla'nın coğrafi işaretli ürünleri olan Milas el halısı, Bodrum mandarini ve Milas zeytinyağının turizm ürününe dönüştürülerek ulusal ve uluslararası pazardaki etkinliğinin artırılmasına yönelik çözüm önerileri sunmuşlardır. Polat (2017) çalışmasında Balıkesir ilinin coğrafi işaretleri örnekleminde turizm ve coğrafi işaret ilişkisini ele almış ve alternatif turizm türlerini bölgeye çekebilmede coğrafi işaretlerin daha etkin kullanılabilmesi için önerilerde bulunmuştur. Polat Üzümcü vd. (2017), Kocaeli'nin coğrafi işaret tescilli ürünleri ile tescil alınabilecek gastronomik ürünlerinin ortaya konması ve bu ürünlerin kırsal turizm açısından değerlendirilmesini amaçlayan çalışmalarında coğrafi işaretler ile kırsal turizm arasındaki ilişki üzerinde durmuşlardır. Çevik (2018) ise coğrafi işaretli ürünlerin turizmdeki rolüne odaklandığ 1 çalışmasında Eskişehir turlarına ilişkin bir içerik analizi gerçekleştirmiş ve Eskişehir'in coğrafi işaret tescilli ürünlerinin tur programlarında ne ölçüde yer aldığını belirlemeye çalışmıştır. Bir başka çalışmada Öz ve Dönmez (2018), yerel gıda ve coğrafi işaretleme ilişkisi ekseninde Mardin'e özgü bir gastronomik ürün olan Süryani şarabına odaklanmış ve Süryani şarabı için coğrafi işaret tescilinin bölgenin gastronomi ve özellikle de şarap turizmi açısından ön plana çıkmasına hizmet edeceğini vurgulamışlardır. Saatçi (2019), coğrafi işaretli gastronomik ürünlerin tanıtım unsuru olarak kullanılma durumlarını araştırdığı çalışmasında 34 ile ait tanıtım broşürlerini incelemiştir. Toplam 91 adet coğrafi işaretli gastronomik ürünü bulunan illerin tanıtım broşürlerinde 197 adet yöresel yiyeceğe yer verildiği görülmüştür. Çalışmada bazı coğrafi 
işaret tescilli gastronomik ürünlerin broşürlerde yer almadığ görülürken tescil alınabilecek yöresel yiyecekler de belirlenmiştir.

Türkiye'de 01.06.2020 tarihi itibariyle 486 ürün coğrafi işaretli olarak tescil edilmişken 511 ürünün de başvuru süreci devam etmektedir. Türkiye'deki coğrafi işaretleme sisteminde sadece gıda ve tarım ürünleri için değil bu kapsam dışında kalan ürünler için de süreç işletilebilmektedir. 2018 yılı sonuna kadar coğrafi işaretleme sistemi içindeki ürün gruplarl; "el sanatları", "gıda", "hayvan", "maden", "tarım" ve "sanayi" türündeki ürünleri kapsarken 2019 yılı itibariyle ürün gruplarında güncellemeye gidilmiştir. Bu kapsamda coğrafi işaretleme sistemindeki güncellenen ürün grupları şu şekildedir (Türk Patent ve Marka Kurumu, 2020b):

* Alkolsüz içecekler

* Bal

* Biralar ve diğer alkollü içkiler

* Çikolata, şekerleme ve türevi ürünler

* Diğer ürünler

* Dokumalar

* Dondurmalar ve yenilebilir buzlar

* Firıncllık ve pastacilık mamulleri, hamur işleri, tatlılar

* Halılar ve kilimler

* Halılar, kilimler ve dokumalar dışında kalan el sanatı ürünleri

* İşlenmiş işlenmemiş et ürünleri

* İşlenmiş ve işlenmemiş meyve ve sebzeler ile mantarlar

* Peynirler

* Peynirler ve tereyağı dışında kalan süt ürünleri

* Tereyağı dâhil katı ve sıvı yağlar

* Yemekler ve çorbalar

* Yiyecekler için çeşni/lezzet vericiler, soslar ve tuz

Tablo 1, 01.06.2020 tarihi itibariyle Türk Patent ve Marka Kurumu verilerinden derlenen coğrafi işaret tescilli ürünlerle ilgili istatistikî bilgileri sunmaktadır. Ancak başvuru sürecinde çok sayıda ürün olduğundan istatistikî bilgilerin sürekli güncellendiğini belirtmekte fayda vardır. 
Tablo 1. Coğrafi İşaret Tescilli Ürün Sayılarn

\begin{tabular}{lll}
\hline Coğrafi İşsaret Türü & Tescilli & Başvuru \\
\hline Menşe adı & 183 & 235 \\
\hline Mahreç işareti & 302 & 269 \\
\hline Geleneksel ürün adı & 1 & 7 \\
\hline Toplam & 486 & 511 \\
\hline
\end{tabular}

Kaynak: Türk Patent ve Marka Kurumu (2020b) resmi internet sitesindeki verilerden derlenerek oluşturulmuştur.

Tablo 2'de coğrafi işaret tescilli ürünlerin ürün gruplarına ve tescil türlerine göre dağılımı yer almaktadır. Toplam 486 tescilli ürünün 302'si mahreç işareti türünde; 183'ü menşe adı türünde iken 1'i ise geleneksel ürün adı türündedir. Ürün gruplarına göre ise en çok tescil alan 3 ürün grubu sırasıyla "işlenmiş ve işlenmemiş meyve ve sebzeler ile mantarlar", "yemekler ve çorbalar" ve "fırıncılık ve pastacılık mamulleri, hamur işleri, tatlılar" gruplarıdır.

Tablo 2. Coğrafi İşaret Tescilli Ürünlerin Ürün Gruplarına Göre Dağılımı

\begin{tabular}{|c|c|c|c|c|}
\hline & $\begin{array}{l}\text { Menşe } \\
\text { adı }\end{array}$ & $\begin{array}{l}\text { Mahreç } \\
\text { işareti }\end{array}$ & $\begin{array}{l}\text { Geleneksel } \\
\text { ürün adı }\end{array}$ & Toplam \\
\hline Alkolsüz içecekler & & 4 & & 4 \\
\hline Bal & 6 & & & 6 \\
\hline Biralar ve diğer alkollü içecekler & 10 & & & 10 \\
\hline Çikolata, şekerleme ve türevi ürünler & 3 & 17 & & 20 \\
\hline Diğer ürünler & 15 & 9 & & 24 \\
\hline Dokumalar & 1 & 25 & & 26 \\
\hline Dondurmalar ve yenilebilir buzlar & & 3 & & 3 \\
\hline Fırıncılık ve pastacılık mamulleri, hamur işleri, tatlılar & 2 & 64 & & 66 \\
\hline Halılar ve kilimler & & 32 & & 32 \\
\hline Halılar, kilimler ve dokumalar dışında kalan el sanatı ürünleri & 5 & 24 & & 29 \\
\hline İşlenmiş işlenmemiş et ürünleri & 5 & 4 & & 9 \\
\hline İşlenmiş ve işlenmemiş meyve ve sebzeler ile mantarlar & 112 & 13 & & 125 \\
\hline Peynirler & 10 & 7 & & 17 \\
\hline Peynirler ve tereyağ1 dışında kalan süt ürünleri & 3 & 1 & & 4 \\
\hline Tereyağı dâhil katı ve sıvı yağlar & 7 & 2 & & 9 \\
\hline Yemekler ve çorbalar & 3 & 95 & 1 & 99 \\
\hline Yiyecekler için çeşni/lezzet vericiler, soslar ve tuz & 1 & 2 & & 3 \\
\hline TOPLAM & 183 & 302 & 1 & 486 \\
\hline
\end{tabular}

Kaynak: Türk Patent ve Marka Kurumu (2020b) resmi internet sitesindeki verilerden derlenerek oluşturulmuştur.

01.06.2020 tarihi itibariyle tescilli 486 tescilli üründen 8'i Türkiye menşeli ve 7'si ise yurtdışı menşeli olarak belirtilmiştir. En çok coğrafi işaret tesciline 
sahip üç şehir sırasıyla Şanlıurfa (29), Gaziantep (26) ve İzmir (18) şeklinde siralanmaktadır.

\section{Yöntem}

\section{Araştırmanın Amacı}

Araştırmanın amacı şehir pazarlamasında coğrafi işaret tescilli ürünlerin kullanımını değerlendirmektir. Bu amaçla 81 ilin belediye, valilik ile il, kültür ve turizm müdürlüğü web siteleri incelenerek şehir pazarlamasında etkin olan kurumların web sitelerinde coğrafi işaret tescilli ürünler hakkında hangi konularda tanıtıcı bilgiler yer aldığı araştırılmıştır.

\section{Araştırmanın Stnirlılikları}

Araştırmaya 81 ilin ilgili kurumlarının web siteleri dâhil edilmiştir. Bazı coğrafi işaret tescilli ürünler ilçe bazlı ün yapmış olsa da şehir pazarlamasında destinasyonun tüm yönleriyle şehrin tamamı olmasından hareketle ilçelere ait kurumların web siteleri araştırmaya dâhil edilmemiştir. Web siteleri analizinde coğrafi işaret tescilli ürünlerle ilgili bilgilerin tanıtıcı bilgi olarak ilgili sekmeler altında yer alması baz alınmıştır. Bu kapsamda "haberler" ya da "duyurular" gibi başlıklar altında yer alan bilgiler kapsam dışı bırakılmıştır.

\section{Veri Toplama ve Analizi}

Araştırmada 11 Haziran 2020 - 10 Temmuz 2020 tarihleri arasında içerik analizi tekniğiyle her şehrin belediye, valilik ve il, kültür ve turizm müdürlüğü web siteleri detaylı bir şekilde incelenerek coğrafi işaret tescilli ürünlerin web sitesinde tanıtılma durumu analiz edilmiştir. Çalışmanın amacıyla bağlantılı olarak coğrafi işaret tescilli ürünler hakkında web sitelerinde sunulan tanitıcı bilgilerin analizinde aşağıdaki konu başlıklarına göre değerlendirme yapılmış ve bu başlıklar Tablo 3'te ilgili numarayla gösterilmiştir:

1. Ürünle ilgili genel bilgiler: Ürünün coğrafi işaret tescil belgesine sahip olduğu, tescil türü, tarihi, ürün tanımı, ayırt edici özellikleri

2. Ürünle ilgili görseller: Fotoğraflar ya da videolar

3. Ürünün kökeni, tarihi süreci: Ürünün nasıl ortaya çıktığı, varsa ortaya çıkış hikâyesi, tarihi süreçte ürünle ilgili yenilikler ve değişimler

4. Ürünün toplumsal değeri: Ürünün ait olduğu toplum için ne ifade ettiği, kültürel detayları, ritüelleri, geleneklere yansıması (bayram, düğün vb.) 
5. Ürünün turistik önemi: Ürünün yöre ve ülke için turistik değeri, ürüne olan turistik talep, ürünün turistlere sunuluş biçimleri, ürünün sunulduğu mekânlar, ürünle ilgili yapılan etkinlikler, ürün özelinde yapılan girişimler

\section{Bulgular}

Tablo 3, coğrafi işaret tescilli ürünlerin şehirlerin web sitelerinde bulunma durumunu göstermektedir. Bir önceki bölümde belirtilen konu başlıklarına (1: Ürünle ilgili genel bilgiler; 2: Ürünle ilgili görseller; 3: Ürünün kökeni, tarihi süreci; 4: Ürünün toplumsal değeri; 5: Ürünün turistik önemi) göre her ilin belediye, valilik ve il kültür ve turizm müdürlüğü web siteleri taranmıştır. Her konu başlığı her ildeki ürünler için üç farklı web sitesinde taranmış olup bu başlıklarla ilgili bilginin verilmiş olduğu web siteleri, Tablo 3'te " $x$ " işareti ile belirtilmiştir. Toplam 486 tescilli ürünün 8'i Türkiye menşeli, 7'si yurtdışı menşeli olduğundan 81 ile ait 471 ürün veri analizine dâhil edilmiştir. Veri analizinin gerçekleştirildiği 11 Haziran - 10 Temmuz tarihleri arasında Kırklareli Belediyesinin web sayfası güncellendiği ve Tunceli İl Kültür ve Turizm Müdürlüğünün web sayfası aktif olmadığı için bu iki web sayfasından veri alınamamıştır.

Tablo 3. Coğrafi İşaret Tescilli Ürünlerin Şehirlerin Web Sitelerinde Bulunma Durumu

\begin{tabular}{|c|c|c|c|c|c|c|c|c|c|c|c|c|c|c|c|c|}
\hline \multirow{2}{*}{ İller } & \multirow{2}{*}{ Coğrafi İşaret Tescilli Ürün Adı } & \multicolumn{5}{|c|}{ Belediye } & \multicolumn{5}{|c|}{ Valilik } & \multicolumn{5}{|c|}{ İl Kül.Tur. Müd. } \\
\hline & & 1 & 2 & 3 & 4 & 5 & 1 & 2 & 3 & 4 & 5 & 1 & 2 & 3 & 4 & 5 \\
\hline \multirow{4}{*}{ Adana } & Adana Kebabı & & & & & & $\mathbf{x}$ & & & & & $\mathbf{x}$ & $\mathbf{x}$ & & $x$ & $x$ \\
\hline & Adana Şalgamı & & & & & & $x$ & & & & & $\mathbf{x}$ & $x$ & & $x$ & $\mathbf{x}$ \\
\hline & Çukurova Pamuğu & & & & & & $x$ & & & & & & & & & \\
\hline & Tapan Bıçağı & & & & & & $\mathbf{x}$ & & & & & & & & & \\
\hline \multirow{4}{*}{ Adiyaman } & Adıyaman Besni Üzümü & & & & & & & & & & & & & & & \\
\hline & Adryaman Etsiz Çiğ Köfte & & & & & & & & & & & & $\mathbf{x}$ & & & \\
\hline & Çelikhan Tütünü & & & & & & & & & & & & & & & \\
\hline & Sincik El Dokuma Halısı & & & & & & & & & & & & & & & \\
\hline \multirow{11}{*}{$\begin{array}{l}\text { Afyon } \\
\text { karahisar }\end{array}$} & Afyon Kaymağı & & $x$ & & & & & $\mathbf{x}$ & & & & $\mathbf{x}$ & $\mathbf{x}$ & & & \\
\hline & Afyon Kaymaklı Ekmek Kadayıfı & & $x$ & & & & & & & & & $\mathbf{x}$ & $x$ & & & \\
\hline & Afyon Mermeri & & $x$ & $\mathbf{x}$ & & & $x$ & $x$ & & & & & $\mathbf{x}$ & & & \\
\hline & Afyon Pastırması & & $x$ & & & & & & & & & $\mathbf{x}$ & $\mathbf{x}$ & & & \\
\hline & Afyon Sucuğu & & $x$ & & & & & & & & & $x$ & $\mathbf{x}$ & & & \\
\hline & Afyonkarahisar Patatesli Ekmeği & & $x$ & & & & & & & & & $\mathbf{x}$ & $x$ & & & \\
\hline & Bayat Türkmen Kilimi & & & & & & & & & & & & $\mathbf{x}$ & & & \\
\hline & Çay İlçesi Vişnesi & & & & & & & & & & & $\mathbf{x}$ & $\mathbf{x}$ & & & \\
\hline & Pazırık El Halısı & & & & & & & & & & & & $\mathbf{x}$ & & & \\
\hline & Süper İnce Kilim & & & & & & & & & & & & $\mathbf{x}$ & & & \\
\hline & Şuhut Keşkeği & & $x$ & & & & & & & & & $\mathbf{x}$ & $\mathbf{x}$ & & & \\
\hline
\end{tabular}


Oraların Nesi Meşhur: Şehir Pazarlamasında Coğrafi İşaret Tescilli Ürünler

\begin{tabular}{|c|c|c|c|c|c|c|c|c|}
\hline & Türkmen El Halısı & & & & $x$ & & & \\
\hline Ağrı & Doğubayazıt Abdigör Köftesi & & $x$ & $x$ & & & $\mathbf{x}$ & \\
\hline \multirow{4}{*}{ Amasya } & Amasya Beji Mermeri & & & & $x$ & & & \\
\hline & Amasya Çiçek Bamyası & & & & $x$ & & & \\
\hline & Amasya Misket Elması & & & & $\mathbf{x}$ & & & \\
\hline & Merzifon Keşkeği & & & & $x$ & & & \\
\hline \multirow{12}{*}{ Ankara } & Ankara Döneri & & & & $\mathbf{x}$ & & & \\
\hline & Ankara Erkeç Pastırması & & & & $x$ & & & \\
\hline & Ankara Simidi & & & & $\mathbf{x}$ & & & \\
\hline & Ankara Tava & & & & $x$ & & & \\
\hline & Beypazarı Kurusu & & & & $x$ & & & \\
\hline & Çubuk Agat Taşı & & & & & & & \\
\hline & Çubuk Turşusu & & & & $\mathbf{x}$ & & & \\
\hline & Gölbaşı Sevgi Çiçeği & $\mathbf{x}$ & & & $\mathbf{x}$ & & & \\
\hline & Kalecik Karası Üzümü & & & & $\mathbf{x}$ & & & \\
\hline & Kızılcahamam Bazlaması & & & & $\mathbf{x}$ & & & \\
\hline & Nallıhan İğne Oyası & & & & & & & \\
\hline & Nallihan Örtmesi & & & & & & & \\
\hline \multirow{7}{*}{ Antalya } & Alanya Avokadosu & & $\mathbf{x}$ & & & & & \\
\hline & Alanya Gülüklü (Hülüklü) Çorba & & & & & & & \\
\hline & Alanya Yenidünyası & & $\mathbf{x}$ & & & & & \\
\hline & Antalya Piyazı & & & & & & & \\
\hline & Antalya Tavşan Yüreği Zeytini & & $x$ & & & & & \\
\hline & Finike Portakalı & & $\mathbf{x}$ & & & & & \\
\hline & Korkuteli Karyağdı Armudu & & $\mathbf{x}$ & & & & & \\
\hline \multirow{2}{*}{ Artvin } & Hopa Laz Böreği & & & & $\mathbf{x}$ & & & \\
\hline & Puçuko & & & & $\mathbf{x}$ & & & \\
\hline \multirow{6}{*}{ Aydin } & Aydın İnciri & & $x$ & & & & & \\
\hline & Aydın Kestanesi & & & & & & & \\
\hline & Çine Köftesi & & & & & & & \\
\hline & Dalama Tandırı & & & & & & & \\
\hline & Nazilli Kar Helvası & & & & & & & \\
\hline & Söke Körüklü Çizmesi & & & & & & & \\
\hline \multirow{11}{*}{ Balıkesir } & Ayvalık Zeytinyağı & & & & & & & \\
\hline & Balıkesir Höşmerim Tatlısı & & & & $\mathbf{x}$ & & & \\
\hline & Balıkesir Kuzu Eti & & & & & & & \\
\hline & Edremit Körfezi Yeşil Çizik Zeytini & & & & & & & \\
\hline & Edremit Zeytinyağı & & & & & & & \\
\hline & Gönen İğne Oyası & & & & $x$ & & & $\mathbf{x}$ \\
\hline & Kapıdağ Mor Soğanı & & & & $x$ & & & \\
\hline & $\begin{array}{l}\text { Marmara Adası Mermeri / Marmara } \\
\text { Mermeri / Marmara Beyazı }\end{array}$ & & & & & & & \\
\hline & Susurluk Ayranı & & & & & & & \\
\hline & Susurluk Tostu & & & & & & & \\
\hline & Yağcibedir El Halısı & & & & $\mathbf{x}$ & $x$ & $x$ & \\
\hline Bilecik & Bilecik Pazaryeri Helvası & & & & $x$ & & & \\
\hline Bingöl & Bingöl Çobantaşı Kavurması & & & & & & & \\
\hline \multirow{2}{*}{ Bitlis } & Adilcevaz Bastonu & & & & $x$ & & & \\
\hline & Ahlat Bastonu & & & & $x$ & & & \\
\hline \multirow{2}{*}{ Bolu } & Bolu Kızılcık Tarhanası & & $\mathbf{x}$ & & $x$ & & & \\
\hline & Göynük Bombay Fasulye & & & & & & & \\
\hline
\end{tabular}




\begin{tabular}{|c|c|c|c|c|c|c|c|c|}
\hline & Göynük Tokalı Örtme & & & & & & & \\
\hline \multirow{3}{*}{ Burdur } & Burdur Ceviz Ezmesi & & $\mathbf{x}$ & $\mathbf{x}$ & & & $\mathbf{x}$ & \\
\hline & Burdur Şiş Köftesi & & $\mathbf{x}$ & $\mathbf{x}$ & & & $\mathbf{x}$ & \\
\hline & Melli İnciri & & & & & & & \\
\hline \multirow{11}{*}{ Bursa } & Bursa Biçağı & & & & & & $\mathbf{x}$ & $\mathbf{x}$ \\
\hline & Bursa İpeği / Bursa İpek İpliği & & & & & & $\mathbf{x}$ & $\mathbf{x}$ \\
\hline & $\begin{array}{l}\text { Bursa Siyah İnciri / Bursa Siyahı / Si- } \\
\text { yah Bursa İnciri }\end{array}$ & & & & & & & \\
\hline & Bursa Şeftalisi & & & & & & & \\
\hline & Gemlik Atı & & & & & & & \\
\hline & Gemlik Zeytini & & & & & & & \\
\hline & Gürsu Deveci Armudu & & & & & & & \\
\hline & İnegöl Köfte & & & & & & $\mathbf{x}$ & $\mathbf{x}$ \\
\hline & İznik Çinisi & & & $\mathbf{x}$ & $\mathbf{x}$ & & $\mathbf{x}$ & $\mathbf{x}$ \\
\hline & Karacabey Soğanı & & & & & & & \\
\hline & Orhangazi Gedelek Turşusu & & & & & & & \\
\hline \multirow{4}{*}{ Çanakkale } & Bayramiç Beyazı & & & & & & & \\
\hline & Bayramiç Elması & & & & & & & \\
\hline & Çanakkale El Halısı & & & & & & $\mathbf{x}$ & \\
\hline & Ezine Peyniri & & & & & & & \\
\hline \multirow{3}{*}{ Çankırı } & Çankırı Sarımsaklı Et & $\mathrm{x} \quad \mathrm{x}$ & & $\mathbf{x}$ & & & & \\
\hline & Çankırı Yoka (İnce) Ekmek Yufkası & $\mathrm{x}$ & & $\mathbf{x}$ & & & & \\
\hline & Çankırı Yumurta Tatlısı & $\mathrm{x} \quad \mathrm{x}$ & & $\mathbf{x}$ & & & $x$ & \\
\hline \multirow{4}{*}{ Çorum } & Çorum Leblebeisi & $\mathrm{x}$ & & & $x$ & $x$ & $\mathbf{x}$ & \\
\hline & İskilip Dolması & $x$ & & & & & $\mathbf{x}$ & \\
\hline & İskilip Turşusu & $x$ & & & & & $\mathbf{x}$ & \\
\hline & Oğuzlar Cevizi & $x$ & & & & & $\mathrm{x}$ & \\
\hline \multirow{7}{*}{ Denizli } & Buldan Bezi & & & & & & & \\
\hline & Çameli Fasulyesi & & & & & & $\mathbf{x}$ & \\
\hline & Denizli Leblebisi & & & & & & & \\
\hline & Denizli Traverteni & & & $\mathbf{x}$ & $\mathbf{x}$ & & $\mathbf{x}$ & \\
\hline & İsabey Çekirdeksiz Üzümü & & & & & & & \\
\hline & Kale Biberi & & & & & & & \\
\hline & Tavas Baklavası & & & & & & $\mathbf{x}$ & \\
\hline \multirow{4}{*}{$\begin{array}{l}\text { Diyarba- } \\
\text { kur }\end{array}$} & Diyarbakır Burma Kadayıfı & & & & & & & \\
\hline & Diyarbakır Karpuzu & & & $\mathbf{x}$ & & $\mathbf{x}$ & & \\
\hline & Diyarbakır Örgü Peyniri & & & & & & & \\
\hline & Karacadağ Pirinci & & & & & & & \\
\hline \multirow{5}{*}{ Edirne } & Edirne Beyaz Peyniri & & & & & & $\mathbf{x}$ & \\
\hline & Edirne Mis Meyve Sabunu & & & $\mathbf{x}$ & $\mathbf{x}$ & $\mathbf{x}$ & $\mathrm{x}$ & $\mathbf{x}$ \\
\hline & Edirne Tava Ciğeri & & & $\mathbf{x}$ & $\mathbf{x}$ & & $\mathbf{x}$ & \\
\hline & İpsala Pirinci & & & $\mathbf{x}$ & & & & \\
\hline & Keşan Satır Et & & & & & & & \\
\hline \multirow{4}{*}{ Elazığ } & Ağın Leblebisi & & & $\mathbf{x}$ & & & $\mathbf{x}$ & \\
\hline & Elazığ Boğazkere Üzümü & & & & & & $\mathbf{x}$ & \\
\hline & Elazığ Orciği & & & $\mathbf{x}$ & $\mathbf{x}$ & & $\mathbf{x}$ & \\
\hline & Elazığ Öküzgözü Üzümü & & & & & & $\mathbf{x}$ & \\
\hline \multirow{3}{*}{ Erzincan } & Cimin Üzümü & $x$ & & $\mathbf{x}$ & $x$ & & $\mathbf{x}$ & \\
\hline & $\begin{array}{l}\text { Erzincan Bakır İmalat ve El İşlemeci- } \\
\text { liği Sanatı }\end{array}$ & & & $\mathbf{x}$ & $\mathbf{x}$ & $\mathbf{x}$ & $\mathbf{x}$ & \\
\hline & Erzincan Tulum Peyniri & $x$ & & $\mathbf{x}$ & $x$ & & $\mathbf{x}$ & \\
\hline
\end{tabular}


Oraların Nesi Meşhur: Şehir Pazarlamasında Coğrafi İşaret Tescilli Ürünler

\begin{tabular}{|c|c|c|c|c|c|c|}
\hline & Refahiye Balı & $x$ & & & $\mathbf{x}$ & $x$ \\
\hline \multirow{10}{*}{ Erzurum } & Erzurum Civil Peyniri & & & $\mathbf{x}$ & $\mathbf{x}$ & \\
\hline & Erzurum Ehram Dokuma Kumaşı & & & $x$ & $x$ & \\
\hline & Erzurum Kadayıf Dolması & & & $\mathbf{x}$ & $\mathbf{x}$ & \\
\hline & $\begin{array}{l}\text { Erzurum Küflü Civil Peyniri (Göğer- } \\
\text { miş Peynir) }\end{array}$ & & & $\mathbf{x}$ & $\mathbf{x}$ & \\
\hline & Hınıs Fasulyesi & & & $\mathbf{x}$ & $x$ & \\
\hline & İspir Kaymağı & & & & & \\
\hline & İspir Kuru Fasulyesi & & & $\mathbf{x}$ & $\mathrm{x}$ & \\
\hline & Karnavas Dut Pekmezi & & & $x$ & $\mathbf{x}$ & \\
\hline & Oltu Cağ Kebabı & & & $x$ & $x$ & \\
\hline & Oltu Taşı & $x$ & & $\mathbf{x}$ & $\mathbf{x}$ & \\
\hline \multirow{4}{*}{ Eskişehir } & Eskişehir Çiğböreği (Çibörek) & & & & $\mathbf{x}$ & \\
\hline & Eskişehir Lüle Taşı & & & & $\mathbf{x}$ & $x$ \\
\hline & Eskişehir Met Helvası & & & & $x$ & \\
\hline & Sivrihisar Muska Baklavası & & & & & \\
\hline \multirow{25}{*}{ Gaziantep } & Antep Baklavası & & $\mathbf{x}$ & & $x$ & \\
\hline & Antep Beyranı & & $x$ & & $x$ & \\
\hline & Antep Bulguru (Gaziantep Bulguru) & & $\mathbf{x}$ & & $\mathbf{x}$ & \\
\hline & Antep Fistığı & & $x$ & & $\mathbf{x}$ & \\
\hline & $\begin{array}{l}\text { Antep FistıkEzmesi (Antepfıstığı Ez- } \\
\text { mesi / Gaziantep Fistık Ezmesi) }\end{array}$ & & $\mathbf{x}$ & & $\mathbf{x}$ & \\
\hline & Antep Firiği & & $\mathbf{x}$ & & $\mathbf{x}$ & \\
\hline & Antep İşi & & $\mathbf{x}$ & & $\mathbf{x}$ & \\
\hline & Antep Katmeri & & $x$ & & $x$ & \\
\hline & $\begin{array}{l}\text { Antep Köy Kahkesi (Gazinetep Köy } \\
\text { Kahkesi) }\end{array}$ & & $\mathbf{x}$ & & $\mathbf{x}$ & \\
\hline & Antep Kurabiyesi & & $\mathbf{x}$ & & $\mathbf{x}$ & \\
\hline & $\begin{array}{l}\text { Antep Kuru Patlıcanı (Gaziantep } \\
\text { Kuru Patlıcanı) }\end{array}$ & & $\mathbf{x}$ & & $\mathbf{x}$ & \\
\hline & Antep Kuntu Kumaşı & & $\mathbf{x}$ & & $\mathbf{x}$ & \\
\hline & $\begin{array}{l}\text { Antep Meyan Şerbeti (Gaziantep } \\
\text { Meyan Şerbeti, Antep Meyankökü } \\
\text { Şerbeti) }\end{array}$ & & $\mathbf{x}$ & & $\mathbf{x}$ & \\
\hline & AntepMuskası (GaziantepMuskası) & & $\mathbf{x}$ & & $\mathbf{x}$ & \\
\hline & $\begin{array}{l}\text { Antep Peyniri / Gaziantep Peyniri / } \\
\text { Antep Sikma Peyniri }\end{array}$ & & $\mathbf{x}$ & & $\mathbf{x}$ & \\
\hline & Antep Şiveydizi & & $\mathbf{x}$ & & $\mathbf{x}$ & \\
\hline & $\begin{array}{l}\text { Antep Tirnaklı Pidesi (Gaziantep } \\
\text { Trrnaklı Pidesi, Antep Pidesi) }\end{array}$ & & $\mathbf{x}$ & & $\mathbf{x}$ & \\
\hline & $\begin{array}{l}\text { Antep Yuvarlaması / Antep Yuvala- } \\
\text { ması }\end{array}$ & & $\mathbf{x}$ & & $\mathbf{x}$ & \\
\hline & Gaziantep Bakır El İşlemeciliği & & $\mathbf{x}$ & & $\mathbf{x}$ & \\
\hline & $\begin{array}{l}\text { Gaziantep Lahmacunu (Antep Lah- } \\
\text { macunu) }\end{array}$ & & $\mathbf{x}$ & & $\mathbf{x}$ & \\
\hline & $\begin{array}{l}\text { Gaziantep Oğuzeli Narı (Antep } \\
\text { Oğuzeli Narı) }\end{array}$ & & $\mathbf{x}$ & & $\mathbf{x}$ & \\
\hline & Gaziantep Sedef El İşlemeciliği & & $\mathbf{x}$ & & $\mathbf{x}$ & \\
\hline & Gaziantep Yeşil Zeytin Böreği & & $\mathbf{x}$ & & $\mathbf{x}$ & \\
\hline & Nizip Nanesi & & $x$ & & $\mathbf{x}$ & \\
\hline & Nizip Sabunu & & & & $\mathbf{x}$ & \\
\hline
\end{tabular}




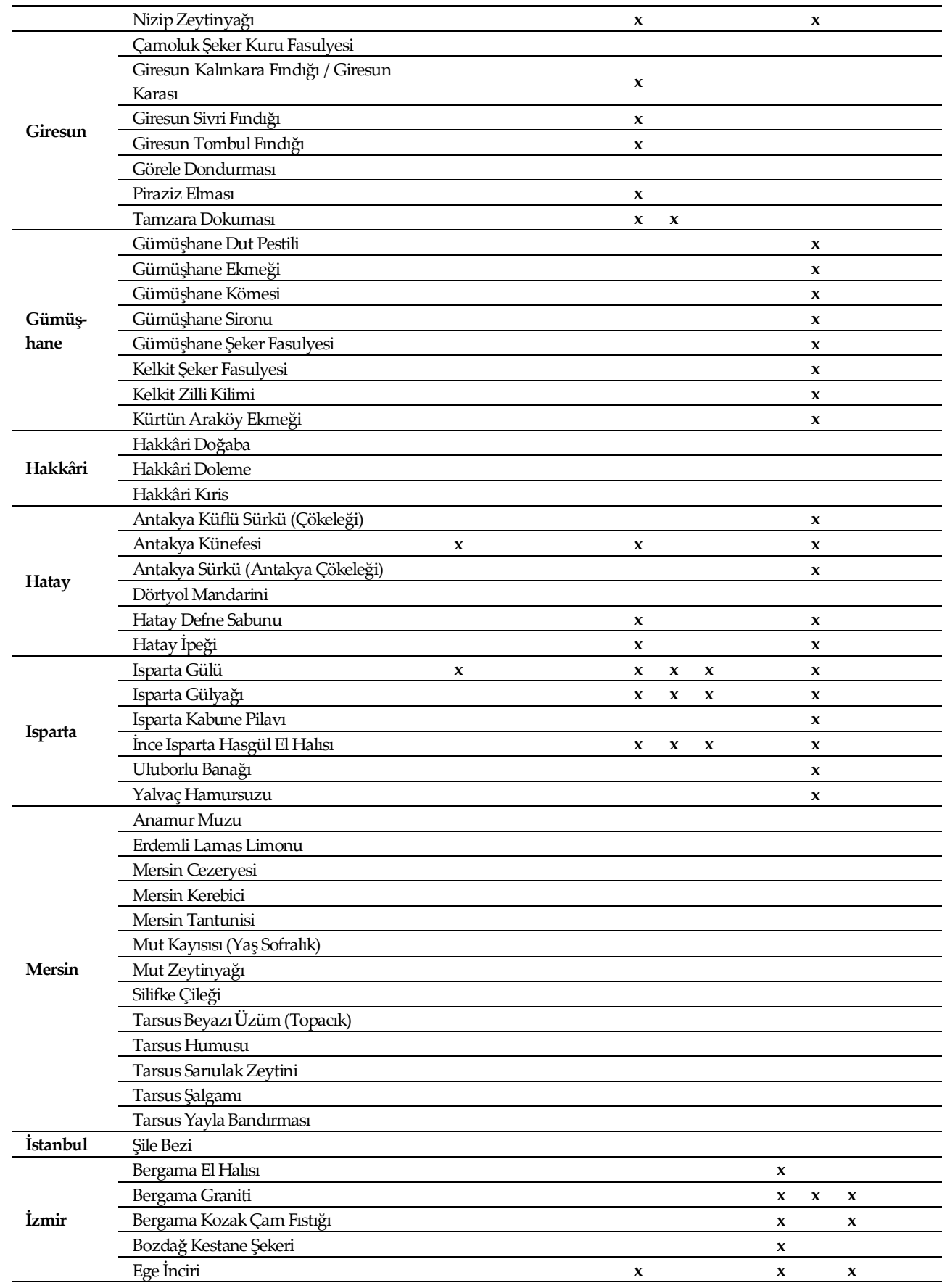




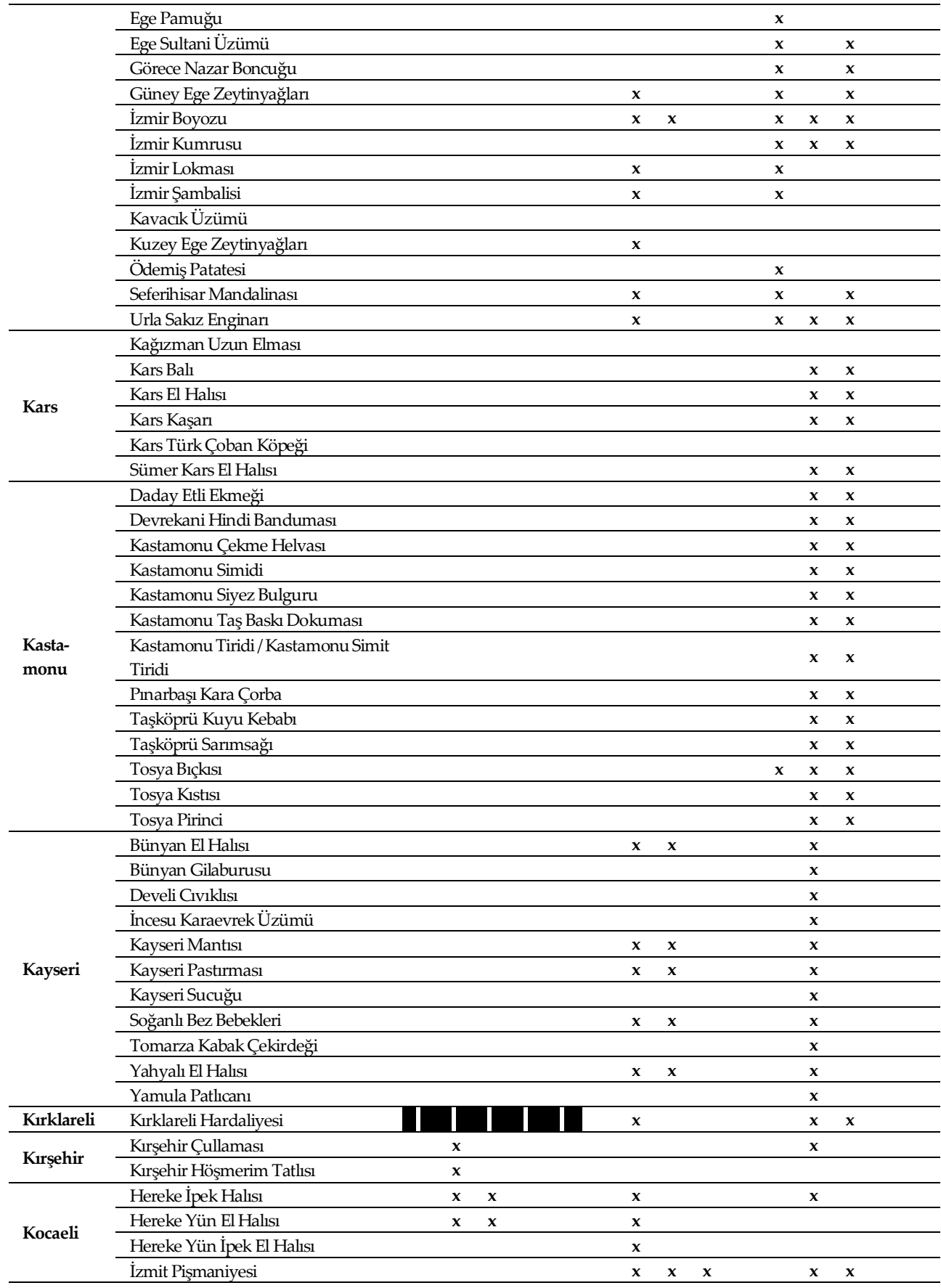




\begin{tabular}{|c|c|c|c|c|c|c|c|c|c|c|c|c|c|}
\hline & İzmit Simidi & & $x$ & $\mathbf{x}$ & & & & & & & & & \\
\hline & Kandıra Bezi & & $x$ & $\mathbf{x}$ & & & & & & & & & \\
\hline & Karamürsel Sepeti & & $x$ & $\mathbf{x}$ & & & & $x$ & $x$ & $x$ & & $x$ & \\
\hline \multirow{8}{*}{ Konya } & Akçabelen (Çetmi) Şeker Fasulyesi & & & & & & & & & & & & \\
\hline & Akşehir Kirazı & & & & & & & & & & & & \\
\hline & Ereğli Beyaz Kirazı & & & & & & & & & & & & \\
\hline & Ereğli Siyah Havucu & & & & & & & & & & & & \\
\hline & Kadınhanı Tahinli Pidesi & & & & & & & & & & & & \\
\hline & Konya Etli Düğün Pilavı & & $x$ & & & & & & & & & & \\
\hline & Konya Etliekmek & & $x$ & & & & & $\mathbf{x}$ & & & & $x$ & \\
\hline & Konya Peynir Şekeri & & & & & & & & & & & & \\
\hline \multirow{4}{*}{ Kütahya } & Kütahya Çinisi & & $x$ & $x$ & $\mathbf{x}$ & $\mathbf{x}$ & & $\mathbf{x}$ & $x$ & & & $x$ & $\mathbf{x}$ \\
\hline & Simav El Halısı & & & & & & & $\mathbf{x}$ & & & & $\mathbf{x}$ & \\
\hline & Şaphane Vişnesi & & & & & & & & & & & $x$ & \\
\hline & Tavşanlı Leblebisi & & & & & & & & & & & $x$ & \\
\hline \multirow{6}{*}{ Malatya } & Akçadağ Halısı & & & & & & $\mathbf{x}$ & $\mathbf{x}$ & $x$ & $\mathbf{x}$ & $\mathbf{x}$ & & \\
\hline & Arapgir Köhne Üzümü & & & & & & & & & & & & \\
\hline & Arapgir Mor Reyhanı & & & & & & & & & & & & \\
\hline & Hekimhan Cevizi & & & & & & & & & & & & \\
\hline & Malatya Dalbastı Kirazı & & & & & & & & & & & & \\
\hline & Malatya Kayısısı & & $x$ & $x$ & $\mathbf{x}$ & $\mathbf{x}$ & & $\mathbf{x}$ & $x$ & $\mathbf{x}$ & $\mathrm{x}$ & $x$ & \\
\hline \multirow{13}{*}{ Manisa } & Akhisar Domat Zeytini & & & & & & & & & & & & \\
\hline & Akhisar Köfte & & & & & & & & & & & $x$ & \\
\hline & Akhisar Uslu Zeytini & & $x$ & & & & & & & & & $x$ & \\
\hline & Gördes El Halısı & & & & & & & & & & & $x$ & $\mathrm{x}$ \\
\hline & Kırkağaç Kavunu & & $x$ & & & & & & & & & & \\
\hline & Kula El Halısı & & & & & & & & & & & $x$ & $x$ \\
\hline & Kula Leblebisi & & & & & & & & & & & & \\
\hline & Manisa Mesir Macunu & & $\mathbf{x}$ & & & & & $\mathbf{x}$ & $\mathbf{x}$ & & & $x$ & $x$ \\
\hline & Manisa Sultani Çekirdeksiz Üzümü & & $x$ & & & & & & & & & $\mathrm{x}$ & \\
\hline & Manisa Taban Simidi & & & & & & & & & & & $x$ & \\
\hline & Salihli Kirazı & & & & & & & & & & & $x$ & \\
\hline & Salihli Odun Köfte & & & & & & & & & & & $x$ & \\
\hline & Yuntdağı El Halısı & & & & & & & & & & & $x$ & $x$ \\
\hline \multirow{12}{*}{$\begin{array}{l}\text { Kahra- } \\
\text { manmaraş }\end{array}$} & Andırın Tirşiği & $x$ & $x$ & & & & & & & & $\mathbf{x}$ & $x$ & $\mathbf{x}$ \\
\hline & Çağlayancerit Cevizi & $\mathbf{x}$ & & & & & & & & & $x$ & $\mathbf{x}$ & $x$ \\
\hline & Kahramanmaraş Hartlap Bıçağı & $x$ & $x$ & & & & & & & & $\mathrm{x}$ & $\mathbf{x}$ & $\mathbf{x}$ \\
\hline & $\begin{array}{l}\text { Kahramanmaraş Oyma Çeyiz San- } \\
\text { dığı }\end{array}$ & $\mathbf{x}$ & $\mathbf{x}$ & & & & & & & & $\mathbf{x}$ & $\mathbf{x}$ & $\mathbf{x}$ \\
\hline & Kahramanmaraş Yemenisi & $\mathbf{x}$ & $\mathbf{x}$ & & & & & & & & $\mathbf{x}$ & $\mathbf{x}$ & $\mathbf{x}$ \\
\hline & Maraş Biberi & $x$ & $x$ & $x$ & & & & & & & $x$ & $\mathbf{x}$ & $x$ \\
\hline & Maraş Burma Bileziği & $x$ & & & & & & & & & $\mathbf{x}$ & $\mathbf{x}$ & $\mathbf{x}$ \\
\hline & Maraş Çöreği & $x$ & & & & & & & & & $x$ & $x$ & $x$ \\
\hline & Maraş Dondurması & $x$ & $x$ & $x$ & & & & $\mathbf{x}$ & $x$ & & $x$ & $x$ & $x$ \\
\hline & Maraş File Nakışı & $x$ & & & & & & & & & $x$ & $x$ & $x$ \\
\hline & Maraş Sumak Ekşisi Akıtı & $x$ & & & & & & & & & $\mathbf{x}$ & $x$ & $x$ \\
\hline & Maraş Tarhanası & $x$ & $x$ & & & & & & & & $\mathbf{x}$ & $x$ & $x$ \\
\hline \multirow{4}{*}{ Mardin } & Mardin İmlebbes & & & & & & & & & & & & \\
\hline & Mardin Bulguru & & & & & & & & & & & & \\
\hline & Mardin İkbebet & & & & & & & $\mathbf{x}$ & & & & $x$ & \\
\hline & Mardin Kaburga Dolması & & & & & & & $\mathbf{x}$ & & & & $x$ & \\
\hline
\end{tabular}


Oraların Nesi Meşhur: Şehir Pazarlamasında Coğrafi İşaret Tescilli Ürünler

\begin{tabular}{|c|c|c|c|c|c|c|c|c|}
\hline & Mardin Kibe & & $\mathbf{x}$ & & & $\mathbf{x}$ & & \\
\hline & Mardin Sembusek & & $\mathbf{x}$ & & & $\mathbf{x}$ & & \\
\hline & Mardin Taşı & & & & & & & \\
\hline \multirow{12}{*}{ Muğla } & Bodrum Mandarini & & & & & & & \\
\hline & Marmaris Çam Balı & & & & & & & \\
\hline & Milas El Halısı & & & & & & & \\
\hline & Milas Tepsi Böreği & & & & & & & \\
\hline & Milas Yağlı Zeytini & & & & & & & \\
\hline & Milas Zeytinyağı & & & & & & & \\
\hline & Muğla Beyaz Mermeri & & & & & & & \\
\hline & Muğla Çam Balı & & & & & & & \\
\hline & Muğla Göce Tarhanası & & & & & & & \\
\hline & Muğla Köftesi & $x$ & & & & & & \\
\hline & Muğla Saraylısı & $x$ & & & & & & \\
\hline & Seydiler Kilimi & & & & & & & \\
\hline \multirow{2}{*}{ Muş } & Muş Çorti Aşı (Yemeği) & & & & & $\mathbf{x}$ & & \\
\hline & Muş Çorti Turşusu & & & & & $\mathbf{x}$ & & \\
\hline \multirow{2}{*}{ Nevşehir } & Avanos Çömleği & & $\mathbf{x}$ & $x$ & & $x$ & & \\
\hline & Nevşehir Kabak Çekirdeği & & & & & & & \\
\hline \multirow{2}{*}{ Niğde } & Bor Sögü̈rmesi & & & & & $\mathbf{x}$ & & \\
\hline & Obruk (Arısama) Halısı & & $\mathbf{x}$ & $\mathbf{x}$ & & $\mathbf{x}$ & $\mathbf{x}$ & \\
\hline \multirow{5}{*}{ Ordu } & Akkuş Şeker Fasulyesi & & & & $x$ & $\mathbf{x}$ & & \\
\hline & Kabataş Helvası & & & & $\mathbf{x}$ & $\mathbf{x}$ & & \\
\hline & Ordu Kivisi & & & & $x$ & $\mathbf{x}$ & & \\
\hline & Ordu Perşembe Ceviz Helvası & & & & $\mathrm{x}$ & $\mathbf{x}$ & & \\
\hline & $\begin{array}{l}\text { Ordu Yayla Pancarı Turşusu / Ordu } \\
\text { Dürme Turşusu }\end{array}$ & & & & $\mathbf{x}$ & $\mathbf{x}$ & & \\
\hline \multirow{6}{*}{ Rize } & Çayeli Kuru Fasulye Yemeği & & & & $x$ & $\mathbf{x}$ & & \\
\hline & Derepazanı Pidesi & & $\mathbf{x}$ & & $x$ & $\mathbf{x}$ & & \\
\hline & Rize Baston Ekmek & & & & $x$ & $\mathbf{x}$ & & \\
\hline & Rize Bezi (Feretiko) & & $\mathbf{x}$ & $\mathbf{x}$ & $\mathbf{x}$ & $\mathbf{x}$ & & \\
\hline & Rize Kavurması & & $\mathbf{x}$ & & $x$ & $\mathbf{x}$ & & \\
\hline & Rize Simidi & & & & $x$ & $\mathbf{x}$ & & \\
\hline \multirow{3}{*}{ Sakarya } & Adapazarı Dartılı Keşkek & & & & & $\mathbf{x}$ & $\mathbf{x}$ & \\
\hline & Adapazarı Islama Köftesi & & $\mathbf{x}$ & $x$ & & $\mathbf{x}$ & $\mathbf{x}$ & \\
\hline & Sakarya Süpürgesi & & $\mathbf{x}$ & & & $\mathbf{x}$ & $\mathbf{x}$ & \\
\hline \multirow{13}{*}{ Samsun } & Bafra Kaymaklı Lokum & & $x$ & & & & & \\
\hline & Bafra Nokulu & $\mathbf{x}$ & $x$ & & $x$ & $\mathbf{x}$ & & \\
\hline & Bafra Pidesi & & $\mathbf{x}$ & & & $\mathbf{x}$ & & \\
\hline & Bafra Zembili & & & & & & & \\
\hline & Çarşamba Pidesi & & & & & & & \\
\hline & Çakallı Menemeni & & & & & & & \\
\hline & Samsun Kaz Tiridi & & & & & & & \\
\hline & Samsun Simidi & & & & & & & \\
\hline & Terme Pidesi & $\mathbf{x}$ & $\mathbf{x}$ & & & & & \\
\hline & Vezirköprü Semaveri & & & & & $x$ & $\mathbf{x}$ & \\
\hline & Vezirköprü Susuz Bezi & & & & & $\mathbf{x}$ & $\mathbf{x}$ & \\
\hline & Vezirköprü Tahtaköprü Kilimi & & & & & $\mathbf{x}$ & $\mathbf{x}$ & \\
\hline & Yakakent Mantısı & & $x$ & & & & & \\
\hline \multirow{2}{*}{ Siirt } & Pervari Balı & & $\mathbf{x}$ & $x$ & & $\mathbf{x}$ & & \\
\hline & Siirt Battaniyesi & & & & & $\mathbf{x}$ & & \\
\hline
\end{tabular}




\begin{tabular}{|c|c|c|c|c|c|c|c|c|c|c|}
\hline & Siirt Büryan Kebabı & & & & & & & $\mathbf{x}$ & $\mathbf{x}$ & \\
\hline & Siirt Perde Pilavı & & & & & & & $x$ & $x$ & \\
\hline \multirow{5}{*}{ Sinop } & Ayancık Göynek Yakası & & & & & & & & & \\
\hline & Ayanckk Keten Bezi & & & & & $x$ & & & & \\
\hline & Boyabat Çemberi & & & & & $x$ & & $\mathbf{x}$ & $x$ & \\
\hline & Boyabat Gazidere Domatesi & & & & & & & & & \\
\hline & Sinop Nokulu & & & & $\mathbf{x}$ & & & & & \\
\hline \multirow{9}{*}{ Sivas } & Gemerek Gilaburusu & & & & & & & & & \\
\hline & Kangal Balıklı Kaplıcası & & & & $\mathbf{x}$ & $x$ & $x$ & $\mathbf{x}$ & & \\
\hline & Kangal Koyunu & & & & $\mathbf{x}$ & $x$ & $\mathbf{x}$ & & & \\
\hline & Sivas Bıçağı & & & & $\mathbf{x}$ & $x$ & $x$ & $x$ & & \\
\hline & Sivas El Halısı & & & & $\mathbf{x}$ & $x$ & $\mathbf{x}$ & $x$ & & \\
\hline & Sivas Katmeri & & $x$ & & & & & $x$ & & \\
\hline & Sivas Köftesi & $x$ & $x$ & & & & & $x$ & & \\
\hline & $\begin{array}{l}\text { Sivas Pezik Turşusu / Sivas PezikDal } \\
\text { Turşusu }\end{array}$ & & & & & & & & & \\
\hline & Şarkışla Kilimi & & & & & & & $\mathbf{x}$ & & \\
\hline \multirow{2}{*}{ Tekirdağ } & Karacakılavuz Dimi Dokuması & & $x$ & & $x$ & $x$ & $x$ & $x$ & & \\
\hline & Malkara Eski Kaşar Peyniri & & & & & & & $\mathbf{x}$ & & \\
\hline \multirow{8}{*}{ Tokat } & Erbaa Narince Bağ Yaprağı & & & & & & & $x$ & & \\
\hline & Niksar Cevizi & & & & & & & $\mathbf{x}$ & & \\
\hline & Tokat Kebabı & & & $\mathbf{x}$ & $\mathbf{x}$ & $x$ & & $\mathbf{x}$ & $\mathbf{x}$ & \\
\hline & $\begin{array}{l}\text { Tokat Narince Salamura Asma Yap- } \\
\text { rağ1 }\end{array}$ & & & & & & & $\mathbf{x}$ & & \\
\hline & Tokat Yazması & & & & & & & $x$ & $\mathbf{x}$ & $x$ \\
\hline & Turhal Yoğurtmacı & & & & & & & $x$ & & \\
\hline & Zile Kömesi & & & & & & & $\mathbf{x}$ & & \\
\hline & Zile Pekmezi & & & & & & & $x$ & & \\
\hline \multirow{8}{*}{ Trabzon } & Akçaabat Köftesi & & & & $\mathbf{x}$ & & & $\mathbf{x}$ & & \\
\hline & Çarşıbaşı Keşanı & & $x$ & $\mathbf{x}$ & $\mathbf{x}$ & & & $x$ & & \\
\hline & Hamsiköy Sütlacı & & & & $x$ & & & $x$ & & \\
\hline & Sürmene Bıçağı & & $x$ & $x$ & $\mathbf{x}$ & $x$ & & $x$ & & \\
\hline & Tonya Tereyağ1 & & $x$ & $x$ & $\mathbf{x}$ & & & $x$ & & \\
\hline & Trabzon Kazaziyesi & & & & $x$ & & & $x$ & $x$ & \\
\hline & Trabzon Telkariye ve Hasırı & & $x$ & $x$ & $\mathbf{x}$ & $x$ & & $x$ & $x$ & \\
\hline & Vakfıkebir Ekmeği & & $x$ & $x$ & $\mathbf{x}$ & & & $x$ & & \\
\hline \multirow{3}{*}{ Tunceli } & Çemişgezek Ulukale Dutu & & & & $x$ & & & & & \\
\hline & Tunceli Sarımsağı & & & & & & & & & \\
\hline & Tunceli Şorbik Çorbası & & & & $x$ & & & & & \\
\hline \multirow{10}{*}{ Şanlıurfa } & Birecik Patlıcanı & & $x$ & & & & & $x$ & & \\
\hline & Karaköprü Narı & & $x$ & & & & & $x$ & & \\
\hline & $\begin{array}{l}\text { Şanlıurfa Açı Ekmeği (Urfa Açk } \\
\text { Ekmeği }\end{array}$ & & $\mathbf{x}$ & & & & & $\mathbf{x}$ & & \\
\hline & Şanlıurfa Biberi & & $\mathbf{x}$ & & $\mathbf{x}$ & & & $\mathbf{x}$ & & \\
\hline & Şanlıurfa Çiğ Köfte & & $x$ & & $\mathbf{x}$ & & & $x$ & & \\
\hline & Şanlıurfa Sadeyağı (Urfa Yağı) & & $x$ & & & & & $x$ & & \\
\hline & Şanlıurfa Tırnaklı Ekmeği & & $x$ & & & & & $x$ & & \\
\hline & Urfa Ciğer Kebabı & & $x$ & & $\mathbf{x}$ & & & $x$ & & \\
\hline & Urfa Eşkili & & $x$ & & & & & $\mathbf{x}$ & & \\
\hline & $\begin{array}{l}\text { Urfa Haşhaş Kebabı / Şanlıurfa Haş- } \\
\text { haş Kebabı }\end{array}$ & & $\mathbf{x}$ & & $\mathbf{x}$ & & & $\mathbf{x}$ & & \\
\hline
\end{tabular}


Oraların Nesi Meşhur: Şehir Pazarlamasında Coğrafi İşaret Tescilli Ürünler

\begin{tabular}{|c|c|c|c|c|c|c|c|c|c|c|c|c|c|c|}
\hline & Urfa İçli Köftesi & $\mathbf{x}$ & & & & & $\mathbf{x}$ & & & & $\mathbf{x}$ & & & \\
\hline & $\begin{array}{l}\text { Urfa Kazan Kebabı / Şanlıurfa Kazan } \\
\text { Kebabı }\end{array}$ & $\mathbf{x}$ & & & & & $\mathbf{x}$ & & & & $\mathbf{x}$ & & & \\
\hline & $\begin{array}{l}\text { Urfa Keme Boranisi Yemeği / } \\
\text { Şanlıurfa Keme Boranisi Yemeği }\end{array}$ & $\mathbf{x}$ & & & & & $\mathbf{x}$ & & & & $\mathbf{x}$ & & & \\
\hline & $\begin{array}{l}\text { Urfa Kıymalı Söğürme / Şanlıurfa } \\
\text { Kıymalı Söğürme }\end{array}$ & $\mathbf{x}$ & & & & & $\mathbf{x}$ & & & & $\mathbf{x}$ & & & \\
\hline & Urfa Lebenisi & $x$ & & & & & & & & & $\mathbf{x}$ & & & \\
\hline & Urfa Meyan Şerbeti (Biyanbalı) & $x$ & & & & & & & & & $\mathbf{x}$ & & & \\
\hline & $\begin{array}{l}\text { Urfa Soğan Kebabı / Şanlıurfa Soğan } \\
\text { Kebabı }\end{array}$ & $\mathbf{x}$ & & & & & & & & & $\mathbf{x}$ & & & \\
\hline & Urfa (Şanlıurfa) Frenk Çömleği & $\mathbf{x}$ & & & & & $\mathbf{x}$ & & & & $\mathbf{x}$ & & & \\
\hline & Urfa (Şanlıurfa) İsot Çömleği & $\mathrm{x}$ & & & & & $\mathbf{x}$ & & & & $\mathrm{x}$ & & & \\
\hline & Urfa (Şanlıurfa) Külünçesi & $\mathbf{x}$ & & & & & & & & & $\mathbf{x}$ & & & \\
\hline & $\begin{array}{l}\text { Urfa (Şanlıurfa) Lahmacunu } \\
\text { (Kıymalı Ekmeği) }\end{array}$ & $\mathbf{x}$ & & & & & $\mathbf{x}$ & & & & $\mathbf{x}$ & & & \\
\hline & Urfa (Şanlıurfa) Patlıcanı Kebabı & $\mathbf{x}$ & & & & & $\mathbf{x}$ & & & & $\mathbf{x}$ & & & \\
\hline & $\begin{array}{l}\text { Urfa (Şanlıurfa) Pencer (Pazı) } \\
\text { Boranisi }\end{array}$ & $\mathbf{x}$ & & & & & $\mathbf{x}$ & & & & $\mathrm{x}$ & & & \\
\hline & Urfa (Şanlıurfa) Su Kabağı Yemeği & $\mathbf{x}$ & & & & & & & & & $\mathbf{x}$ & & & \\
\hline & Urfa (Şanlıurfa) Üzlemeli Pilavı & $\mathbf{x}$ & & & & & $\mathbf{x}$ & & & & $\mathbf{x}$ & & & \\
\hline & $\begin{array}{l}\text { Urfa Şıllık Tatlısı (Şanlıurfa } \\
\text { Şıllık Tatlısı) }\end{array}$ & $\mathbf{x}$ & & & & & $\mathbf{x}$ & & & & $\mathrm{x}$ & & & \\
\hline & Urfa Tiriti (Şanlıurfa Tiriti) & & & & & & & & & & $x$ & & & \\
\hline & Urfa Yumurtalı Köfte & $\mathbf{x}$ & & & & & & & & & $\mathbf{x}$ & & & \\
\hline & Urfa Zerdesi (Şanlıurfa Zerdesi) & $\mathbf{x}$ & & & & & & & & & $\mathbf{x}$ & & & \\
\hline \multirow{3}{*}{ Uşak } & Eşme Yörük Kilimi & $\mathrm{x}$ & $\mathbf{x}$ & & $x$ & & & & & & $\mathrm{x}$ & $x$ & $x$ & \\
\hline & Uşak Halısı & $\mathbf{x}$ & $\mathbf{x}$ & $\mathbf{x}$ & $\mathbf{x}$ & & & & & & $\mathrm{x}$ & $\mathbf{x}$ & & \\
\hline & Uşak Tarhanası & & & & & $\mathbf{x}$ & $\mathbf{x}$ & $x$ & $x$ & $x$ & & & & \\
\hline \multirow{6}{*}{ Van } & Jirkan Kilimi & & & & & & & & & & $\mathbf{x}$ & $\mathbf{x}$ & $x$ & \\
\hline & Murtuğa & & & & & & & & & & & & & \\
\hline & Van Kavut & & & & & & & & & & & & & \\
\hline & Van Keledoşu & & & & & & & & & & & & & \\
\hline & Van Otlu Peyniri & & & & & & & & & & $\mathbf{x}$ & $x$ & & \\
\hline & Van Savatlı Gümüş İşlemesi & & & & & & & & & & $\mathrm{x}$ & $x$ & & $\mathbf{x}$ \\
\hline \multirow{4}{*}{ Yozgat } & Yozgat ArabaşıSı & & & & & & & & & & $\mathbf{x}$ & & & \\
\hline & Yozgat Çanak Peyniri & & & & & & & & & & $x$ & & & \\
\hline & Yozgat Parmak Çöreği & & & & & & & & & & $x$ & & & \\
\hline & Yozgat Tandır Kebabı & & & & & & & & & & $\mathrm{x}$ & & & \\
\hline \multirow{2}{*}{$\begin{array}{l}\text { Zongul- } \\
\text { dak }\end{array}$} & Çaycuma Manda Yoğurdu & & & & & & $\mathbf{x}$ & & $\mathbf{x}$ & & & & & \\
\hline & Devrek Bastonu & & & & & & $\mathbf{x}$ & & $\mathbf{x}$ & & $x$ & & & \\
\hline \multirow{3}{*}{ Aksaray } & Aksaray İnceelek Tatlısı & & & & & & & & & & & & & \\
\hline & Aksaray Tulum Kebabı & & & & & & & & & & & & $x$ & \\
\hline & Taşpınar El Halısı & & & & & & & & & & & $\mathbf{x}$ & & \\
\hline \multirow{4}{*}{ Bayburt } & Bayburt Ehramı & & & & & & & & & & & $x$ & $x$ & \\
\hline & Bayburt Lor Dolması & & & & & & & & & & & & & \\
\hline & Bayburt Taşı & & & & & & & & & & & & & \\
\hline & Bayburt Tatlı Çorba & & & & & & & & & & & & & \\
\hline Karaman & $\begin{array}{l}\text { Karaman Divle Obruğu Tulum Pey- } \\
\text { niri }\end{array}$ & & & & & & & & & & $\mathbf{x}$ & & & \\
\hline Kurıkkale & Kırıkkale Keskin Tava & & & & & & & & & & $\mathbf{x}$ & & & \\
\hline
\end{tabular}




\begin{tabular}{|c|c|c|c|c|c|c|c|c|c|c|c|c|c|}
\hline & Kırıkkale Kılıçlar Soğanı & & & & & & & & & & & & \\
\hline Batman & Batman Şam Böreği & & & & $\mathbf{x}$ & & & & & & & & \\
\hline Şırnak & Şımşıpe & & & & & & & & & $x$ & & & \\
\hline Bartın & Bartın İşi Telkırma & & $\mathbf{x}$ & & $x$ & $\mathbf{x}$ & & & $\mathbf{x}$ & $\mathbf{x}$ & $\mathrm{x}$ & $x$ & \\
\hline \multirow{3}{*}{ Ardahan } & Ardahan Çiçek Balı & $\mathbf{x}$ & & $\mathbf{x}$ & $\mathbf{x}$ & & & & & & & & \\
\hline & Damal Bebeği & & & & $\mathbf{x}$ & $\mathbf{x}$ & & $x$ & & & & & \\
\hline & Posof Elması / Badele Elması & & & & & & & & & & & & \\
\hline \multirow{2}{*}{ Iğdır } & Iğdır Kayısısı & & & & & & & & & & & & \\
\hline & Iğdır Taş Köfte Yemeği & & & & $x$ & & & & & $\mathbf{x}$ & & & \\
\hline Yalova & Çınarcık İşi & & & & $\mathbf{x}$ & $x$ & & & & & & & \\
\hline \multirow{4}{*}{ Karabük } & Eflani Cember Bezi & & & & & & & & & & & & \\
\hline & Eflani Hindi Bandırması & & & & & & & & & & & & \\
\hline & Safranbolu Lokumu & & & & $\mathbf{x}$ & $x$ & & & & & & & \\
\hline & Safranbolu Safranı & & & & $\mathbf{x}$ & $x$ & & & & & & & \\
\hline \multirow[t]{2}{*}{ Kilis } & $\begin{array}{l}\text { Cennet Çamuru / Kilis Kaymaklı } \\
\text { Kırma Künefe }\end{array}$ & & & & $\mathbf{x}$ & & & & & $\mathbf{x}$ & & & \\
\hline & Kilis Katmeri & & & & $\mathbf{x}$ & & & & & $\mathbf{x}$ & & & \\
\hline Osmaniye & Osmaniye Yer Fıstığı & & & & $\mathbf{x}$ & $x$ & $\mathbf{x}$ & $\mathbf{x}$ & & $x$ & & & \\
\hline \multirow{6}{*}{ Düzce } & Akçakoca Mancarlı Pidesi & & & & & & & & $\mathbf{x}$ & $x$ & $x$ & $x$ & $x$ \\
\hline & Akçakoca Melengücceği Tatlısı & & $x$ & $x$ & & & & & $x$ & $x$ & $x$ & $x$ & $x$ \\
\hline & Akçakoca Sarı Findığı & & & & & & & & $\mathbf{x}$ & $\mathbf{x}$ & $x$ & $x$ & $\mathbf{x}$ \\
\hline & Düzce Acıkası & & & & & & & & $x$ & $\mathbf{x}$ & $x$ & $x$ & $x$ \\
\hline & Düzce Köftesi & & & & & & & & $\mathbf{x}$ & $\mathbf{x}$ & $x$ & $x$ & $\mathbf{x}$ \\
\hline & Konuralp Pirinci & & & & & & & & $\mathbf{x}$ & $x$ & $\mathrm{x}$ & $x$ & $x$ \\
\hline
\end{tabular}

Tablo 4'te ürünlerle ilgili bilgi verilmesi konusunda belediyeler, valilikler ve il kültür ve turizm müdürlükleri açısından genel bir kıyas yapılmaktadır. Bazı illerde (Osmaniye, Iğdır, Yalova, Şırnak vb.) sadece tek bir coğrafi işaret tescilli ürün bulunurken bazı illerde ise (Şanlıurfa: 29, Gaziantep: 26, İzmir: $18 \mathrm{vb}$.) çok sayıda coğrafi işaret tescilli ürünün bulunması nedeniyle il bazında kıyas yapılmamıştır.

Tablo 4. Şehirlerin Web Sitelerinde Coğrafi İşaret Tescilli Ürünlerle İlgili Konu Başlıklarının Bulunma Sıklı̆̆ı

\begin{tabular}{llllll}
\hline Belediye & $\mathbf{1}$ & $\mathbf{2}$ & $\mathbf{3}$ & $\mathbf{4}$ & $\mathbf{5}$ \\
\hline Ürün Sayıs1 & 471 & 471 & 471 & 471 & 471 \\
\hline Verilen Bilgi Sayısı & 15 & 84 & 19 & 4 & 5 \\
\hline $\mathbf{\%}$ & $\mathbf{3 , 1}$ & $\mathbf{1 7 , 8}$ & $\mathbf{4 , 0}$ & $\mathbf{0 , 8}$ & $\mathbf{1 , 0}$ \\
\hline Valilik & $\mathbf{1}$ & $\mathbf{2}$ & $\mathbf{3}$ & $\mathbf{4}$ & $\mathbf{5}$ \\
\hline Ürün Sayıs1 & 471 & 471 & 471 & 471 & 471 \\
\hline Verilen Bilgi Sayıs1 & 12 & 151 & 49 & 18 & 7 \\
\hline $\mathbf{\%}$ & $\mathbf{2 , 5}$ & $\mathbf{3 2 , 0}$ & $\mathbf{1 0 , 4}$ & $\mathbf{3 , 8}$ & $\mathbf{1 , 4}$ \\
\hline İl Kültür ve Turizm Müdürlüğ̈̈ & $\mathbf{1}$ & $\mathbf{2}$ & $\mathbf{3}$ & $\mathbf{4}$ & $\mathbf{5}$ \\
\hline Ürün Sayıs1 & 471 & 471 & 471 & 471 & 471 \\
\hline Verilen Bilgi Sayısı & $\mathbf{6 6}$ & $\mathbf{2 9 6}$ & 81 & $\mathbf{1 8}$ & 10 \\
\hline $\mathbf{\%}$ & $\mathbf{1 4 , 0}$ & $\mathbf{6 2 , 8}$ & $\mathbf{1 7 , 1}$ & $\mathbf{3 , 8}$ & $\mathbf{2 , 1}$ \\
\hline
\end{tabular}


Tablo 4'te şehirlerin belediye, valilik ve il kültür ve turizm müdürlükleri web sitelerinde ilgili konu başlıklarının bulunma sıklı̆̆ı verilmiştir. Üç farklı kurum açısından bakıldığında coğrafi işaret tescilli ürünlerle ilgili tescile dair genel bilgi verilme sıklı̆̆ının çok az olduğu görülmektedir. Yani ürünler web sitesinde tanitım unsuru olarak kullanılmasına rağmen ürünlerin coğrafi işaret tescilli olduğu bilgisi ve bu tescile dair ayrıntılar çok nadir bulunmaktadır. Bilgi verilme sıklıklarına bakıldığında valilik ve il kültür ve turizm müdürlüklerinin web sitelerinde ürünlerle ilgili görsellerin bulunması sıklıkları \%30'un üzerindedir. Bunun dişında bulunan tüm konu başlıklarında bu oran \%20'nin altındadır. Bununla birlikte her üç kurum web sitelerinin ürünlerin toplumsal değeri ve turistik önemini belirtme sıklıklarının $\% 4^{\prime}$ ten az olduğu görülmektedir.

Kurumlar arası bir değerlendirme yapıldığında ise beş konu başlığının toplamına göre coğrafi işaret tescilli ürünlerle ilgili bilgi verme konusunda birinci sırada toplam 471 içerikle il kültür ve turizm müdürlüğü web siteleri bulunmaktadır. İkinci sırada toplam 237 içerikle valilik web siteleri bulunurken üçüncü sırada ise toplam 127 içerikle belediye web siteleri bulunmaktadir.

\section{Tartışma ve Sonuç}

Coğrafi işaret tescilli ürünler, bir şehrin özgün kimliğinin bir parçasını oluşturması bakımından şehrin turizm pazarlaması ve tanıtım faaliyetlerinde çok önemli bir konumda bulunmaktadırlar. T.C. Kültür ve Turizm Bakanlığı Tanıtma Bülteni'nde (2018) de bu konuya değinilerek coğrafi işaret tescilli ürünlerin yöreyi ve ürünü birlikte tanıtarak kültürel yerel çekicilikleri, kültürel yerel mimariyi, geleneksel değerleri ilgi odağı haline getirme ve yöresel ürünleri turistik ürün haline dönüştürme gibi özellikleri bulunduğundan bahsedilmiştir. Böylelikle destinasyonların, farkındalığı artırma ve tanıtıma ilişkin stratejiler geliştirerek markalaşan ürün ve destinasyon olma özelliğine kavuşabildikleri vurgulanmıştır. Şehir pazarlaması çalışmalarında coğrafi işaret tescilli ürünlere ağırlık vermek ve şehri tescilli ürünlerle birlikte pazarlamak şehri markalaşma yolunda avantajlı konuma getirmektedir.

Üretildiği yöreye özgü özellikler taşıyan coğrafi işaret tescilli ürünlerin pazarlama ve tanıtım çalışmalarında etkin bir şekilde kullanılması için bazı noktalara dikkat edilmesi gerekmektedir. Ürünün sadece coğrafi işaret tesciline 
sahip olduğunun bilgisinin verilmesi bu tanıtım çalışmalarında yeterli olmamaktadır. Coğrafi işaret tescilli ürünler ve turizm ilişkisinde sadece ekonomik kazanımların değil aynı zamanda bu ilişkinin geçmişten gelen kültürel mirası sürdürmeye yönelik katkıların da üzerinde durulması gerektiğini belirten Çevik (2018, 2019a, 2019b), bu ürünlerin turizm ve tanıtım amaçlı kullanımında ürünlerin tanımı, ayırt edici özellikleri, kültürel detayları, hikâyeleri, toplumsal değerleri gibi bilgilerin de mutlaka aktarılması gerektiğini öne sürmüştür. Bu noktadan hareketle bu çalışmada şehirlerin web sitesi üzerinden yaptıkları tanıtım çalışmalarında coğrafi işaret tescilli ürünlere ne ölçüde yer verdikleri ve bu ürünlerle ilgili hangi bilgileri web sitelerinde bulundurdukları analiz edilmiştir. Yapılan analizde, web sitelerinde ürünün coğrafi işaret tescili aldığı bilgisi, ürün görseli, ürünün kökeni ve ortaya çıkış hikâyesi, ürünün toplumsal değeri ve turistik önemine dair bilgilerin olup olmadığı araştırılmıştır.

Çalışmanın bulgularından çıkan en dikkat çekici sonuç, birçok kurumun web sitesinde tescilli ürünlerle ilgili veriler yer alırken bu ürünlerin coğrafi işaret tescilli ürün olduğuna dair bilgi bulunmayışıdır. Bu bağlamda kurumlar açısından coğrafi işaret tescilli ürün sahibi olmanın şehir ve şehrin tanıtımı için ne kadar önemli olduğu konusunda yeterli düzeyde farkındalığa sahip olmadıkları söylenebilir. Bununla birlikte incelenen kurumlar arasında bu konuya gereken önemi veren başarılı örneklere de rastlanmıştır. Bazı kurumların web sitelerinde "coğrafi işaretli ürünlerimiz" sekmesi altında tescilli ürünler hakkında bilgi verildiği görülmüştür. Bu kapsamda coğrafi işaret tescilli ürün tanıtımını üst düzeyde önemseyen bu örneklerin tanıtım ve turizm açısından da yeterli bir web sitesine sahip oldukları yorumu yapılabilir.

Çalışmanın bulgularından çıkan bir diğer sonuç, her üç kurum türü aç1sindan da ortak bir nokta olarak ürün görsellerini yeterli düzeyde kullanmış olduklarıdır. Hatta bazı durumlarda coğrafi işaret tescilli ürünlerle ilgili olarak web sitelerinde sunulan tek bilgi ürünle ilgili fotoğraftır. Ancak görsel öğelerin, açıklayıcı ve tanıtıı bilgilerle desteklenmemiş olması başka bir ifade ile ürün bilgisinin yetersizliği dikkat çekici bir sonuçtur.

Coğrafi işaret tescilli ürünlerle ilgili web sitelerinde araştırılan bir diğer konu da ürünlerin kökeni ve tarihi sürecidir. Bu bağlamda ürünün nasıl ortaya çıktığı, varsa hikâyesi ve tarihi süreçte günümüze kadar ne gibi değişimler geçirdiği ile ilgili bilgilerin web sitesinde bulunması, ürünle ilgili bir merak uyandıracağı gibi turizm açısından da bir çekicilik oluşturacaktır. Ancak 
çalışmanın bulgularından da görüldügü gibi kurumlar tanıtım noktasında bu konuya yeterince önem vermemektedir. Bu noktada coğrafi işaret tescilli ürünlerin ortaya çıkış hikâyelerinin üzerine gidilmesi ve turizm açısından çekicilik yaratabilmesi maksadıyla bu hikâyelerle bağlantılı sloganlar geliştirilmesi faydalı olabilir.

Çalışmada araştırılan 4 ve 5 numaralı konu başlıkları ise kurumların web sitelerinde neredeyse hiç yer vermediklerini söyleyecek kadar düşük düzeyde kalmıştır. Coğrafi işaret tescilli ürünlerin toplum için ne ifade ettiği, kültürel detayları, ritüelleri, geleneklere yansıması ve ürünlerin şehirlerde sunulduğu mekânlar, sunuluş biçimleri, ürünle ilgili yapılan etkinlikler ya da girişimler, turistlerin tatil öncesi araştırma yaparken merak ettikleri ve ilgi çekebilecek konulardır. Bu anlamda bu konu başlıkları aynı zamanda şehrin kimliğinin bir parçasını da yansıtmakta ve şehrin markalaşma sürecinde de önem taşımaktadır. Bu konularla bağlantılı olarak birçok kurumun web sitesinde dikkat çeken nokta, gastronomik ürünlerle ilgili olarak yemeğin sadece tarifinin verilmiş olmasıdır. Yemeğin tarifinin verilmiş olmasının, turizm anlamında herhangi bir katkı sağlamayacağı açıtır. Ürünün tarifi verilerek bunu evde yapabilirsiniz imajı vermek yerine, yerinde yenmezse, yerinde tüketilmezse, yerinden alınmazsa bir değeri olmayacağı önemle vurgulanarak bir çekim gücü yaratılmalıdır. Bu anlamda bu ürünleri tüketmek isteyenleri de şehirlere çekmek önemli bir strateji olacaktır.

Özetlemek gerekirse çalışmanın bulguları, her üç kurum türü için de özellikle gastronomik ürünlerde sadece yemek tarifi verildiği, coğrafi işaret tescilli ürünlerle ilgili belirlenen konu başlıkları ile ilgili bilgi düzeylerinin çok az olduğu ya da hiç olmadığı, bu durumun web sitelerinin tasarım bağlamında hedefinin turizm ve tanıtma açısından bir hamle olmasından uzak olduğunu ortaya koymaktadır. Bu durum özellikle belediye ve valilik web siteleri açısından literatürdeki bazı çalışma sonuçları (Ertaş vd., 2020; Güçer vd., 2013; Gümüş, 2018; Ünal ve Çelen, 2020) ile benzerlik göstermekte ve kurumların web site tasarımlarını daha çok yerel halka yönelik gerçekleştirdiğini, turizm ve tanıtma bağlamında verilen bilgilerin yetersiz olduğunu açığa çıkarmaktadır. Bununla birlikte valilik ve il kültür ve turizm müdürlüğü web sayfalarının görsel olarak düzenleri ve web sayfa yapılarında bir standardın bulunduğu görülürken coğrafi işaret tescilli ürünlerin tanıtımı konusunda bu standarttan oldukça uzak oldukları söylenebilir. 
Coğrafi işaret tescilli ürünlerin günümüzde değerinin ve ne anlama geldiğinin tam olarak anlaşılmadığı ya da kurumlar tarafından verilen önemin yeterli olmadığı, bununla birlikte bu konuda çalışmalar yapan ve gereken önemi veren kurumların bulunduğu fakat genele oranla sayılarının yok denilebilecek kadar az olduğu söylenebilir. Bu anlamda çalışma kapsamında coğrafi işaret tescilli ürünlerden turizm ve tanıtım bağlamında azami düzeyde yararlanabilmek için kurumlara bazı öneriler sunulmuştur:

- Tescil edilmesi ürünün özgün değerini ortaya çıkarmaktadır. Bu tescilin net bir şekilde vurgulanması gerekmektedir.

- Tescilli ürünlerle ilgili gerçekleştirilen festivallerin sayısı artırılmalı ve gerçekleşen ya da gerçekleşmesi planlanan festival içerikleri ayrı bir sekme altında web sitesinde sunulmalıdır. Böylelikle etkinlik turizmi ve gastronomi turizmi potansiyelinden yararlanılarak şehre turist çekilebilir.

- Coğrafi işaret tescilli ürünlerle ilgili belgesel çekimleri yapılabilir ve belgesellerin tanitımı kurumların web siteleri ya da resmi sosyal medya sayfalarında ilgi uyandırıcı bir şekilde yapılabilir. Ayrıca gezi içerikli programlar ya da sosyal medyada fenomen olan gezginler şehre davet edilerek ürün tanıtımının daha geniş kitlelere ulaşması sağlanabilir.

- Özellikle coğrafi işaret tescilli gastronomik ürünlerin tanıtımında tarif vermek yerine o ürünü en iyi üreten veya yapan kişilerle video içerikleri üretilebilir ve bunlar kurumların web siteleri ya da sosyal medya sayfalarında paylaşılabilir.

- Şehir pazarlaması açısından ürünün katkısı unutulmamalıdır. Şehirlerin katılacakları ulusal ya da uluslararası fuarlarda şehrin kimliğini yansıtan bu ürünlerin değeri vurgulanarak tanıtıcı gücü ortaya çıarılabilir.

- Coğrafi işaret tescilli ürünler özelinde yapılacak çeşitli proje ve girişimler de (Örn. Maraş Dondurma Müzesi, Hatay Gastronomi Evi gibi) şehirlerin markalama çalışmalarına önemli katkılar sağlayacaktır.

- Kurumlar kendilerine ait yayınlar yapabilir. Veri analizi sürecinde en çok göze çarpan nokta, coğrafi işaret tescilli ürünle ilgili bilgi veren web sitelerinde Coğrafi İşaretleme Sisteminde bulunan tescil bilgilerinin aynen web sitelerine konulmasıdır. Bu anlamda kurumlarda turizm ve tanitım konusunda uzman personel istihdam edilip o ürüne ilgili şehrin gözüyle yaklaşılarak özgün çalışmalar gerçekleştirilebilir. 
- İl kültür ve turizm müdürlükleri bir şehrin tanıtımında lokomotif rolü oynamalıdır. Bu anlamda ürünleri ve şehri tanitma, çekim gücü oluşturma gibi temel görevleri üstlenmeleri ve bunun için çeşitli organizasyonlar, projeler, işbirlikleri gibi girişimlerde bulunarak şehrin tanitıminda başat rolü oynamaları gerekmektedir. Ayrıca coğrafi işaret tescilli ürünlerin tanıtımı konusunda bir standart belirlenerek her şehrin il kültür ve turizm müdürlüğü web sitesinde ayrı bir sekme oluşturulmalıdır. $\mathrm{Bu}$ çalışmada coğrafi işaret tescilli ürünlerin web sitelerinde tanıtımı konusunda Türkiye çapında iller bazında genel bir durum değerlendirmesi yapılması amaçlanmıştır. Bu nedenle tanıtım konusunda şehirler arasında bir karşılaştırma yapma amacı güdülmemiştir. Gelecek çalışmalarda bölgeler ya da şehirler bazında coğrafi işaret tescilli ürünlerin tanıtım unsuru olarak kullanılmasına yönelik karşılaştırma amaçlı daha detaylı analizler yürütülebilir.

Bu çalışmada sadece şehirlere ait kurumların web sayfaları analiz edilmiştir. Bu anlamda ilçelere ait kurumların web sayfaları çalışma kapsamı dışında bırakılmıştır. Şehirlerin, şehir pazarlamasında tüm destinasyonlarıyla bir bütün olarak ele alınması gerekliliğinden hareketle ilçe bazlı girişimlerle tescil alınan ürünlere ait bilgilerin de mutlaka şehir yönetimindeki kurumların web sitelerinde bulunması gerekmektedir. 


\title{
EXTENDED ABSTRACT
}

\section{What is Famous There: Geographical Indication Registered Products in City Marketing}

\author{
Samet Çevik - Semih Sariipek \\ Bandırma Onyedi Eylül University
}

While all stakeholders in the city have a role in city marketing, local governments have important duties. Local governments play an important role in promoting and shaping tourism development. Today, the internet has a great role as an effective tool in marketing the elements that make up the identity of cities as well as in the marketing of tourism regions. The aim of this research is to evaluate the use of geographical indication registered products in city marketing. For this purpose, the web sites of 81 provinces of municipalities, governorships and provincial, culture and tourism directorates were examined. The web sites of these institutions that are active in city marketing have analyzed the subjects on which introductory information about the geographical indication registered products.

There are many studies in the literature focusing on the role of the geographical indication registered products in tourism. Orhan (2010) addressed the contributions of the geographical indication registered products of Kocaeli to the city in cultural, economic, touristic and social contexts, and made some suggestions by determining the production problems. In another study, Şahin (2013) examined the potential products of the Vize district of Kırklareli province and evaluated the benefits that these products could provide to the region in case of registration. Mercan and Üzülmez (2014) investigated the importance of geographical indication registered products of Çanakkale province in regional tourism development. One of the most important conclusions from the study is that the promotional activities of the products have not been done enough. Yenipınar et al. (2014) conducted a research on Van herbal cheese by referring to the use of geographical indication as a tool to develop regional tourism. As a result of the research, it was concluded that the geographical registration of Van herbal cheese is a powerful tool that will benefit the tourism development, promotion and economy of 
the province by creating a branded product. Yanar and Özkan Tağı (2014) identified geographically indication registered products belonging to the province of Burdur in their studies and developed original product recommendations for touristic souvenir design. Vatansever Deviren and Yldiz (2017) evaluated the role of geographical indications in regional tourism in the Muğla sample. The authors presented solutions to increase the effectiveness of Muğla's geographically indication registered Milas handmade carpets, Bodrum mandarins and Milas olive oil into tourism products and increase their effectiveness in the national and international market. Polat (2017) discussed the relationship between tourism and geographical indication in the sample of the geographically indication registered products of Balıkesir province and made suggestions for the more effective use of geographical indications in attracting alternative tourism types to the region. Polat Üzümcü et al. (2017) focused on the relationship between geographical indications and rural tourism in their studies aiming to reveal Kocaeli's registered products and gastronomic products that can be registered and to evaluate these products in terms of rural tourism. On the other hand, Çevik (2018) conducted a content analysis of Eskişehir tours in his study focusing on the role of geographically indication registered products in tourism and tried to determine the extent of Eskişehir's registered products in tour programs. In another study, Öz and Dönmez (2018) focused on Assyrian wine, a gastronomic product unique to Mardin, in the axis of the relationship between local food and geographical indication, and emphasized that the geographical sign registration for Syriac wine will serve the region to come to the fore in terms of gastronomy and especially wine tourism. Saatçi (2019) investigated the use of geographically indication registered gastronomic products as promotional elements and examined the promotional brochures of 34 cities. In the study, it was seen that some gastronomic products registered were not included in the brochures, and local foods that could be registered were also determined.

Between June 11-July 10, 2020, the websites of municipalities, governorships and the provincial, culture and tourism directorates of each city were examined in detail with content analysis technique, and the status of the products with geographical indication registered on the website was analyzed.

The websites of the relevant institutions of 81 provinces were included in the research. Although some geographical indication registered products have a district-based reputation, since the destination is the whole city in all 
aspects of city marketing, the websites of the institutions belonging to the districts were not included in the study.

Considering from the perspective of three different institutions, it is seen that the frequency of giving general information about the geographical indication registered products is very low. In other words, although the products are used as promotional items on the website, the information that the products are registered as a geographical indication and the details of this registration are very rare.

When an inter-institutional evaluation is made, according to the sum of five topics, the provincial directorate of culture and tourism web sites take the first place in providing information about products registered as geographical indications with a total of 471 contents. In the second place are governorship websites with a total of 237 content, while the third is municipality websites with a total of 127 content.

It can be said that the value and meaning of the geographical indication registered products are not fully understood today or the importance given by the institutions is not sufficient, however, there are institutions that work on this subject and give the necessary importance, but their number is almost negligible compared to the general.

\section{Kaynakça / References}

Ashworth, G. J. ve Voogd, H. (1988). Marketing the city: Concepts, processes and Dutch applications. The Town Planning Review, 59(1), 65-79.

Can, A. S., Alaeddinoğlu, F. ve Türker, N. (2014). Local authorities participation in the tourism planning process. Transylvanian Review of Administrative Sciences, $41 \mathrm{E}$, 190-212.

Çevik, S. (2018). Coğrafi işaretli ürünlerin turizmdeki rolü: Eskişehir turlarına ilişkin bir içerik analizi. Journal of Recreation and Tourism Research, 5(4), 21-44.

Çevik, S. (2019a). Gastronomik kimlik, (Ed) Yıldırım Saçlık, M. ve Çevik, S.: Bir Yerin Tabaktaki Kimliği içinde (s. 15-30) Ankara: Detay Yayıncllk.

Çevik, S. (2019b). Eskişehir' in coğrafi işaret tescilli ürünü çiböreğin kültürel ifadesi. III. Uluslararası Turizm ve Kültürel Miras Kongresi, 24-28 Nisan, Muğla, 332-344.

Durlu Özkaya, F., Sünnetçioğlu, S. ve Can, A. (2013). Sürdürülebilir gastronomi turizmi hareketiligüinde coğrafi işaretlemenin rolü. Journal of Tourism and GastronomyStudies, 1(1), 13-20. 
Ertaş, M., Kaygalak Çelebi, S. ve Kurlar Can, B. (2020). Şehir turizminde belediyelerin rolü: Büyükşehir web sitelerinin incelenmesi. Journal of Tourism and Gastronomy Studies, 8(2), 1076-1091.

Güçer, E., Hassan, A. ve Pelit, E. (2013). Destinasyon pazarlamasinda belediye web sayfalarmnn önemi: Türkiye'deki büyükşehir belediyelerinde bir inceleme. Manas Sosyal Araştrrmalar Dergisi, 2(4), 47-62.

Gümüş, N. (2018). Sosyal medyanın kamu kurumları tarafindan kamusal pazarlama aracı olarak kullanılmass: 81 il valiliği üzerindebir araştırma. AïÜ Sosyal Bilimler Enstitüsü Dergisi, 18(4), 189-212.

Kan, M. ve Gülçubuk, B. (2008). Kursal ekonominin canlanmasinda ve yerel sahiplenmede coğrafi işaretler. U. Ü. Ziraat Fakültesi Dergisi, 22(2), 57-66.

Kan, M., Gülçubuk, B. ve Küçükçongar, M. (2012). Coğrafi işaretlerin kursal turizmde kullanılma olanakları. KMÜ Sosyal ve Ekonomik Arasttrmalar Dergisi, 14(22), 93101.

Kavaratzis, M. ve Ashworth, G. J. (2006). City branding: An effective assertion of identityor a transitory marketing trick? Place Branding, 2(3), 183-194.

Mercan, Ş. O. ve Üzülmez, M. (2014). Coğrafi işaretlerin bölgesel turizm gelişimindeki önemi: Çanakkale ili örneği. Dokuz Eylül Üniversitesi İktisadi ve İdari Bilimler Fakültesi Dergisi, 29(2), 67-94.

Coğrafi işaretlerin korunmast hakkanda kanun hükmünde kararname. (2018). Resmi Gazete. Say1: 22326. 13.10.2018 tarihinde http://www.mevzuat.gov.tr/MevzuatMetin/4.5.555.pdf adresinden erişildi.

Orhan, A. (2010). Yerel değerlerin turizm ürününe dönüştürülmesinde "coğrafi işaretlerin" kullanımı: İzmit pişmaniyesi örneği. Anatolia: Turizm Araştırmalarn Dergisi, 21(2), 243-254.

Öz, H. ve Dönmez, B. (2018). Yerel gıda ve coğrafi işaretleme kapsamında Süryani şarabının değerlendirilmesi. Güncel Turizm Araştırmalan Dergisi, 2(2), 260-269.

Polat, C. (2007). Şehir pazarlaması, dünyadaki ve Türkiye'deki gelişmeler ve karşlaşılan sorunlar. Selçuk Üniversitesi Sosyal Bilimler Meslek Yüksekokulu Dergisi, 10(1-2), 231258.

Polat, E. (2017). Turizm ve coğrafi işaretleme: Balkesir örneği. Meriç Uluslararası Sosyal ve Stratejik Araştirmalar Dergisi, 1(1), 17-31.

Polat Üzümcü, T., Alyakut, Ö. ve Adalet Akpulat, N. (2017). Coğrafi işaretleme kapsaminda Kocaeli gastronomik ürünlerinin değerlendirilmesi. KMÜ Sosyal ve Ekonomik Araştrmalar Dergisi, 19(28), 132-140. 
Rainisto, S. K. (2003). Success factors of place marketing: A study of place marketing practices in Northern Europe and the United States. Yayınlanmamış Doktora Tezi. Helsinki: Helsinki University of Technology.

Saatçi, G. (2019). Coğrafi işaretli yiyeceklerin tanıtım unsuru olarak yöresel yemekler kapsaminda değerlendirilmesi. Journal of Tourism and Gastronomy Studies, 7(1), 358-374.

Şahin, G. (2013). Coğrafi işaretlerin önemi ve Vize (Kurklareli)'nin coğrafi işaretleri. Pamukkale Üniversitesi Sosyal Bilimler Enstitüsü Dergisi, 15, 23-37.

T.C. Kültür ve Turizm Bakanlığı Tanıtma Genel Müdürlüğü (2018). Tanıtma Bülten, 16.

Türk Patent ve Marka Kurumu (2019). Coğrafi işaretler ve geleneksel ürün adı amblemleri. 02.07.2020 tarihinde https://www.turkpatent.gov.tr/TURKPATENT/resources/temp/20259A72-5C47-4DF5-898C-D0E681A10C31.pdf adresinden erişildi.

Türk Patent ve Marka Kurumu (2020a). Coğrafi işaretler ve geleneksel ürün adları. 02.07.2020 tarihinde $\quad$ https:/www.turkpatent.gov.tr/TURKPATENT/resources/temp/68EA9618-BA4A-49C8-A1B5-0DC9A5BCDF36.pdf adresinden erişildi.

Türk Patent ve Marka Kurumu (2020b). Türkiye'nin coğrafi işaretleri veri tabanı. 01.06.2020 tarihinde https://www.ci.gov.tr/veri-tabani adresinden erişildi.

Vatansever Deviren, N. ve Yıldız, O. (2017). Coğrafi işaretlerin bölgesel turizm açısından değerlendirilmesi: Muğla örneği. The Journal of Academic Social Science Studies, 62, 511-523.

Yanar, A. ve Özkan Tağı, S. (2014). Burdur iline ait coğrafi işaretlerin belirlenmesi ve özgün turistik hediyelik eşya tasarım önerileri. Art-e Sanat Dergisi, Teke Yöresi Kültürel Değerleri Özel Sayısı, 29-41.

Yenipınar, U., Köşker, H. ve Karacaoğlu, S. (2014). Turizmde yerel yiyeceklerin önemi ve coğrafi işaretleme: Van otlu peyniri. Journal of Tourism and Gastronomy Studies, 2(2), 13-23.

Ünal, A. ve Çelen, O. (2020). Destinasyon pazarlama araçlarının web sitelerinin değerlendirilmesine yöneliknitel bir araştırma: Akdeniz destinasyonları örneği. Süleyman Demirel Üniversitesi Vizyoner Dergisi, 11(26), 30-44.

\section{Kaynakça Bilgisi / Citation Information}

Sariipek, S. ve Çevik, S. (2020). Oraların nesi meşhur: Şehir pazarlamasinda coğrafi işaret tescilli ürünler. OPUS-Uluslararası Toplum Araştırmaları Dergisi, 16(32), 4907-4938. DOI: 10.26466/opus.772918 